\title{
The Secretion of Toxins and Other Exoproteins of Cronobacter: Role in Virulence, Adaption, and Persistence
}

\author{
Hyein Jang ${ }^{1}$, Gopal R. Gopinath ${ }^{1}$, Athmanya Eshwar ${ }^{2}$, Shabarinath Srikumar ${ }^{3}$, Scott Nguyen ${ }^{3}$, \\ Jayanthi Gangiredla ${ }^{1}$, Isha R. Patel ${ }^{1}$, Samantha B. Finkelstein ${ }^{1}$, Flavia Negrete ${ }^{1}$, JungHa Woo ${ }^{1}$, \\ YouYoung Lee ${ }^{1}$, Séamus Fanning ${ }^{3}$, Roger Stephan ${ }^{2}\left(\mathbb{D}\right.$, Ben D. Tall ${ }^{1, * \mathbb{D}}$ and Angelika Lehner ${ }^{2}(\mathbb{D}$ \\ 1 Center for Food Safety and Applied Nutrition, U.S. Food and Drug Administration, Laurel, MD 20708, USA; \\ hyein.jang@fda.hhs.gov (H.J.); gopal.gopinathrao@fda.hhs.gov (G.G.); \\ Jayanthi.Gangiredla@fda.hhs.gov (J.G.); isha.patel@fda.hhs.gov (I.P.); sfinkel6@terpmail.umd.edu (S.F.); \\ flavianegrete@yahoo.com (F.N.); junghaa12@gmail.com (J.W.); luy902@naver.com (Y.L.) \\ 2 Institute for Food Safety and Hygiene, University of Zurich, Zurich CH-8006 Zürich, Switzerland; \\ athmanya.eshwar@uzh.ch (A.E.); stephanr@fsafety.uzh.ch (R.S.); lehnera@fsafety.uzh.ch (A.L.) \\ 3 UCD-Centre for Food Safety, Science Centre South, University College Dublin, Dublin Belfield, Dublin 4, \\ D04 V1W8, Ireland; ssrikumar@uaeu.ac.ae (S.S.); scott.nguyen@ucd.ie (S.N.); sfanning@ucd.ie (S.F.) \\ * Correspondence: ben.tall@fda.hhs.gov
}

Received: 23 December 2019; Accepted: 6 February 2020; Published: 8 February 2020

\begin{abstract}
Cronobacter species are considered an opportunistic group of foodborne pathogenic bacteria capable of causing both intestinal and systemic human disease. This review describes common virulence themes shared among the seven Cronobacter species and describes multiple exoproteins secreted by Cronobacter, many of which are bacterial toxins that may play a role in human disease. The review will particularly concentrate on the virulence factors secreted by C. sakazakii, C. malonaticus, and $C$. turicensis, which are the primary human pathogens of interest. It has been discovered that various species-specific virulence factors adversely affect a wide range of eukaryotic cell processes including protein synthesis, cell division, and ion secretion. Many of these factors are toxins which have been shown to also modulate the host immune response. These factors are encoded on a variety of mobile genetic elements such as plasmids and transposons; this genomic plasticity implies ongoing re-assortment of virulence factor genes which has complicated our efforts to categorize Cronobacter into sharply defined genomic pathotypes.
\end{abstract}

Keywords: virulence factors; protein secretion systems; quorum sensing systems; outer membrane proteins; osmotic stress response; efflux pumps; plasmids; adherence factors; iron transport

\section{Introduction}

Cronobacter species are considered an opportunistic group of foodborne pathogens capable of causing both intestinal and systemic human disease. There are seven species that are taxonomically recognized within the genus: Cronobacter sakazakii, Cronobacter malonaticus, Cronobacter turicensis, Cronobacter muytjensii, Cronobacter dublinensis, Cronobacter universalis, and Cronobacter condimenti [1-3]. Except for $C$. condimenti, all species of Cronobacter have been isolated from clinical specimens. Cronobacter has always been considered a neonatal pathogen, but it can infect other susceptible individuals such as older infants and elderly individuals alike and continues to attract media attention locally, nationally, and internationally [4-15]. Urmenyi and Franklin, in 1961, reported the first cases of fatal invasive newborn infections (meningitis) caused by Cronobacter species (reported as a yellow-pigmented Enterobacter cloacae) [16]. Furthermore, Cronobacter was elevated to a global foodborne and public 
health issue when contaminated lots of powdered infant formula (PIF) or follow-up formula (FUF) were epidemiologically linked to several neonatal and infant septicemia/meningitis outbreaks [17-19]. In addition to meningitis, the range of Cronobacter infantile infections have been extended now to include necrotizing enterocolitis (NEC) and bacteremia or sepsis; death can occur within hours from the onset of symptoms $[4-9,11,13,16,17]$.

PIF was thought to be the source of neonatal/infantile infections. However, it is clear now that contamination of reconstituted PIF can occur intrinsically and extrinsically, although the main reservoir(s) and routes(s) of contamination have yet to be determined [18-20]. Jason reported surveillance data on 82 Cronobacter cases (between 1958 and 2010) and showed that these infants became ill (defined here as a confirmed culture-positive case of septicemia or meningitis) after ingesting breast milk exclusively (without consumption of PIF, FUF, or powdered human milk fortifiers) prior to illness onset [11]. Friedemann had also reported similar observations [20]. To underscore this point, Bowen et al. [21] and McMullan [22] recently reported infantile cases of C. sakazakii septicemia/meningitis where these infants only consumed expressed maternal milk (EMM) during the first weeks after birth. Contaminated personal breast pumps were found to be the source of the contamination. Pulsed-field gel electrophoresis (PFGE) and whole genome sequencing (WGS) analyses of isolates determined that the clinical isolates were indistinguishable with those cultured from a contaminated breast pump and a home kitchen sink drain in the first case and the breast pump in the latter case. Together, these data suggest that breast feeding and EMM recommendations from health care individuals need to be better communicated to nursing mothers. Of equal significance is that Cronobacter species are largely more ecologically widespread and have been found associated with many types of foods besides infant formula products. For example, Cronobacter species have been found associated with dried dairy protein products (milk and cheese protein powders), cereals, candies such as licorice and lemon-flavored cough drops, dried spices, teas, nuts, herbs, and pastas and water [4,23-25]. It has also been found associated with many different ready-to-eat and frozen vegetables, insect body surfaces and intestinal contents, and man-made environments such as PIF or dairy powder production facilities, and household sink drains [23,24,26-29].

Cronobacter display a variety of unique features which support the organism's capability to survive under various stressful growth environments and these attributes may also be beneficial to the organism when it interacts with humans [27,30]. This review will discuss common themes of virulence shared among the seven Cronobacter species and describe multiple exoproteins secreted by Cronobacter, many of which are bacterial toxins which may play a role in human disease. Even though all but $C$. condimenti has been associated with human disease we will particularly concentrate on some proteins or virulence factors secreted by C. sakazakii, C. malonaticus and C. turicensis, which are the primary human pathogens of interest.

\section{Common Themes in Cronobacter Virulence}

Like with most enteric pathogens that interact with humans, the human mucosa or mucus membrane is the first site of contact that allows Cronobacter species to follow a well-recognized bacterial infection stratagem comprising of: (i) colonization at a mucosal site, e.g., intestinal, respiratory, or the urinary tract epithelia, (ii) circumvention, subversion, and exploitation of host defenses, e.g., invasion of intestinal epithelial cells or internalization and survival within phagocytic cells, which may also provide the pathogen a niche with less competition from other microorganisms, as well as provision of new and rich nutrients, (iii) systemic spread and multiplication, e.g., within the blood, phagocytes, or at extra-intestinal sites such as the meninges, and (iv) host damage, e.g., through expression of exoproteins such as toxins and/or damage due to pro-inflammatory modulation of the host immune system. In fact, Cruz-Córdova et al. provided evidence that the flagellum of Cronobacter species can induce inflammatory cytokines, such as IL-8, TNF- $\alpha$, and IL-10 [31].

One of the most highly conserved phenotype expressed by Cronobacter species is their capacity to colonize the intestinal mucosal surface and compete for nutrients in the presence of the gut microbiome, 
despite the action of peristalsis [32]. The expression of adherence factors such as fimbriae or pili and outer membrane protein adhesins is a common trait possessed by all Cronobacter strains and represents various classes of secreted and polymerized exoproteins [32,33]. However, other than genomic findings showing the presence of such genes and gene clusters within respective genomes, little information is known about mechanisms of intestinal adherence. On the other hand, biofilm formation by Cronobacter species on common materials used in PIF manufacturing (and other food production environments) has been well documented both experimentally and within commercial manufacturing environments [27,34-37]. A biofilm is comprised of microorganisms and occurs when cells stick to each other as they colonize a surface. These adherent cells become embedded within a matrix of extracellular polymeric substances. Additionally, the flagellum subunit FliC found to be involved in the Cronobacter auto agglutination phenotype was noted by Hoeflinger and Miller [38]. However, the role of flagella in biofilm formation needs further investigation. The formation of biofilms is mediated by quorum sensing and is based on the synthesis, secretion, and cellular detection of signaling molecules [39]. Extracellular concentrations of these signaling molecules are sensed by cells of the pathogen and upon reaching a population density-dependent threshold, allows the induction of targeted gene expression of the entire cell population in a highly coordinated and controlled fashion.

Once host colonization has been established, the pathogenomic strategies that Cronobacter strains possess can be remarkably different. General disease paradigms that have been described for infant Cronobacter infections include: necrotizing enterocolitis, pneumonia, septicemia or meningitis. Additionally, similar infections are observed in adults such as septicemia and pneumonia; but other types of adult infections have also emerged such as wound and urinary tract infections (UTI) [10,13-15].

As is the case for many enteric pathogens, another common feature possessed among Cronobacter species is that they carry plasmids, which are known to be involved in contributing to genomic plasticity, bacterial virulence, and survival [40]. In general, such plasmids have been found among members of the Enterobacteriaceae that encode a diversity of virulence factors, such as harboring genes for antibiotic resistance, toxins, adherence factors, and secretion systems (types 3, 4, and 6), and it is thought that plasmid-borne virulence genes (or gene clusters) are acquired through horizontal gene transfer (HGT) [40-46]. In silico analysis of such plasmids harbored by Cronobacter species suggests that this common theme holds true here as well [47]. In fact, Muytjens et al. was the first group to identify and characterize plasmids possessed by clinical Cronobacter strains (reported as E. sakazakii) [48]. The strains were acquired during a 6-year surveillance study of neonatal meningitis and septicemia cases. Other researchers performed similar studies [49-51], which also revealed that such strains (reported as E. sakazakii) possessed multiple sized plasmids, and these strains were isolated from ill infants, utensils used to prepare infant formula which was consumed by the infants, and from containers of PIF formulations. Since then, whole genome sequencing (WGS) has allowed for the study of plasmids at the genomic level and during 2010-2011, the first closed genomes of C. sakazakii strain BAA-894 and C. turicensis strain LMG23827 ${ }^{\mathrm{T}}$ were made available [33,52]. Franco et al. [47] used this information to characterize two plasmids, pESA3 and pCTU1 harbored by these strains. WGS analysis revealed that plasmids pESA3 (131 kbp), pCUNV1 (129 kbp), and pCTU1 (138 kbp), respectively encode a single and shared RepFIB-like (incompatibility class) origin of replication gene, rep $A$, as well as two iron acquisition gene clusters, eit $C B A D$ ( $\mathrm{ABC}$ ferric-iron transporter) and iuc $A B C D / i u t A$ (hydroxamate-type siderophore aerobactin, named Cronobactin) $[33,52,53]$. Figure 1 shows the sequence homology shared between these three virulence plasmids. The iucABCD/iut $A$ gene cluster is the only known Cronobacter siderophore present among the seven species even though multiple iron acquisition systems have been described [54]. This redundancy in iron acquisition genes (gene clusters) may reflect the niche diversity occupied by Cronobacter species (such as eukaryotic plants, PIF manufacturing facilities, and flies to name a few), as well as the disposition and bioavailability of various sources of iron within these unique environments. 


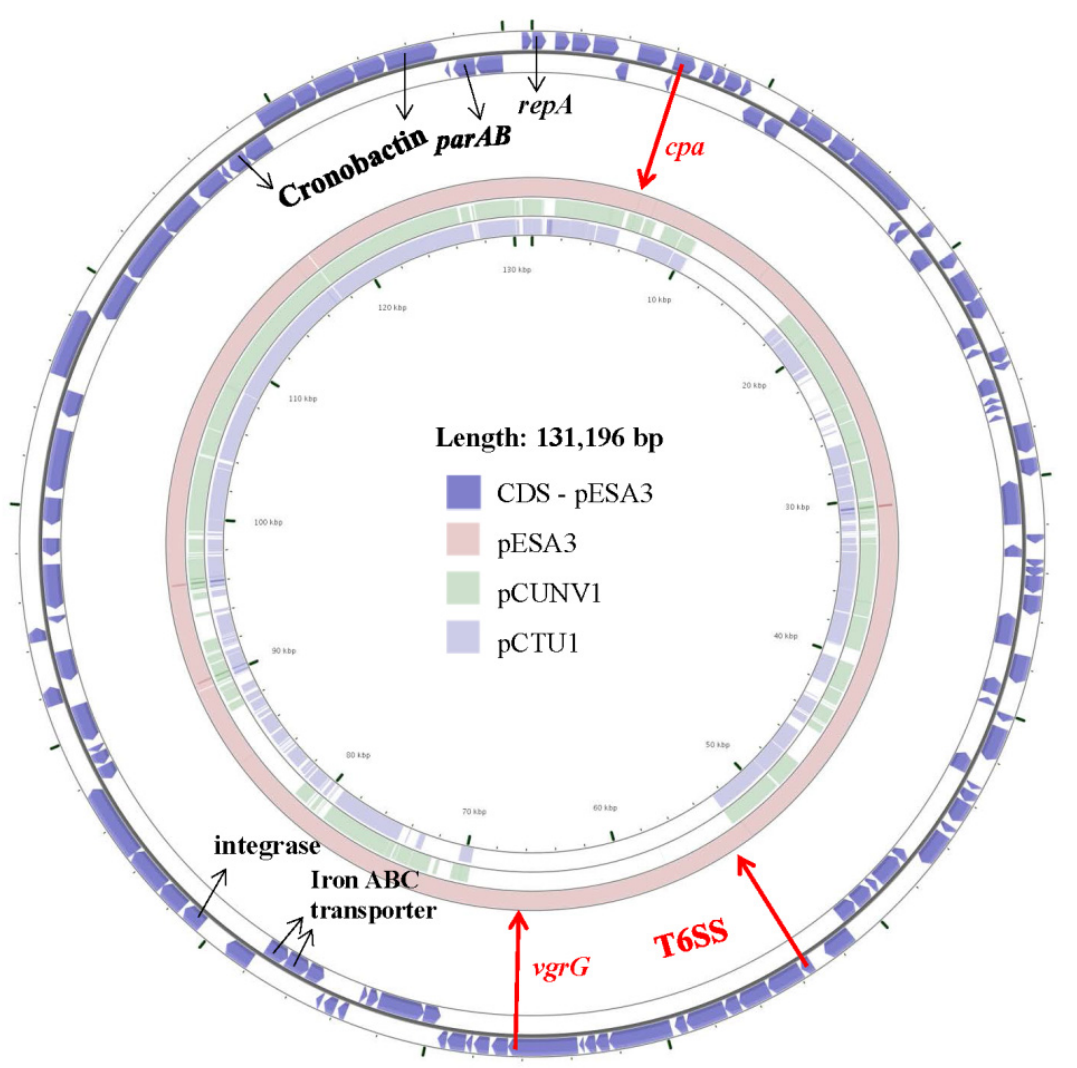

Figure 1. Sequence alignment of pESA3, pCS2, pSP291-1 and pCTU1 produced on the CGView Server from the Stothard Research Group [55] that uses BLAST analysis to illustrate conserved and missing genomic sequences (Available online: http://stothard.afns.ualberta.ca/cgview_server/; last accessed 12/20/2019). Two circular plasmid genomes, pCUNV1 (NZ_CP012258) and pCTU1 (NC_013283), were compared against the reference pESA3 (NC_009780). GenBank annotations of the reference pESA3 (CDS in blue arranged in two outside rings) were downloaded as a GFF file for analysis using the default configuration on the CGView server. Select genes or loci of interest are shown as across the circular genomes as follows: Siderophore loci with Cronobactin gene, Iron ABC transporter genes, Type 6 Secretion System (T6SS), parAB genes and the toxin cpa gene are adapted from Franco et al. [47]. Missing regions identified by the BLAST analysis on the CGView server are shown as 'gaps' on each of the two circular genomes. Genes and loci missing in pCUNV1 or pCTU1 plasmids are in red. As expected, T6SS is seen only on the reference pESA3 from C. sakazakii while the toxin encoding cpa gene is absent in the plasmid pCTU1 from C. turicensis. Figure was adapted from Jang et al. [56].

Reports by Liu et al. [57] and Zogaj et al. [58] showed that Cronobacter can colonize the gastrointestinal tract without causing disease. However, more epidemiological information is required to understand its function as a member of the gut microbiota, and whether its presence represents transient colonization of particular strains or other types of host-associations and how different bacteria adapt and evolve for example, many bacteria are "commensal pathogens", i.e., able to cause disease in some people and be harmless in others.

\section{Cronobacter sakazakii}

Cronobacter sakazakii, as described by Iversen et al. [1] consists of a group of strains previously reported by Farmer et al. [59] as belonging to biogroups 1-4, 7, 8, 11, and 13 of the former E. sakazakii species epithet. C. sakazakii is the predominant Cronobacter species associated with infantile and adult illnesses [4-8,13-15,18]. Using the multi-locus sequence typing (MLST) scheme described by Baldwin et al. [60], Joseph et al. [61], and Joseph and Forsythe [62] showed an association among particular $C$. sakazakii sequence types (ST), which are found with specific types of illnesses $[63,64]$. For example, 
C. sakazakii ST4 was found to be associated with infantile septicemia and meningitis cases $[15,64]$. Other clinically important STs include C. sakazakii ST1, ST8, ST12, ST15, ST40, ST107, ST110 and ST111. Interestingly, Joseph and Forsythe reported that $C$. sakazakii possessing the ST profiles of ST15, ST97, ST107, ST108, and ST110 are highly related to those possessing the ST4 allelic profile and represent a group of strains forming a clonal complex, CC4 [62]. Clonal complexes represent strains that have single, double, or triple loci variants among the seven MLST alleles and just one nucleotide difference in one locus results in an assignment of a different allelic profile number. Furthermore, $C$. sakazakii possessing the ST12 alleles have been found associated with necrotizing enterocolitis cases [65]. C. sakazakii is strongly associated with severe and often fatal cases of necrotizing enterocolitis and meningitis in neonates and infants.

Interestingly, whole genome sequencing analysis has revealed that $C$. sakazakii possess a nanAKT gene cluster which allows for the utilization of exogenous sialic acid which is found in breast milk, infant formula, intestinal mucin, and gangliosides in the brain. Currently only a few strains have been analyzed, but laboratory studies reported by Joseph et al. [66] confirmed that only C. sakazakii, and not the other six Cronobacter species, was able import and catabolize sialic acid which also suggests that the organism may have adapted to the human host driven by these known reserves of sialic acid.

A study reported by Alsonosi et al. identified 51 isolates from two hospitals located in the Czech Republic and they found a preponderance of $C$. sakazakii ST4 strains among adult cases of pneumonia, wound infections, and UTIs, which suggests that $C$. sakazakii ST4 may also be emerging as an adult pathogen [15]. Currently there is not enough epidemiological information to tease apart community-acquired infections from nosocomial infections. In addition to the clinically significant ST1, ST4, and ST8 strains being found associated with PIF manufacturing environments in North America, Europe and China, other important STs are ST31, ST40, ST64, ST83, ST103, ST196, ST194, and ST190 [26,67].

\section{Cronobacter malonaticus}

Cronobacter malonaticus, as described by Iversen et al. [1], comprises strains that were previously reported by Farmer et al. [59] as belonging to biogroups 5, 9, and 14 of the former E. sakazakii species epithet. As the species' name implies, C. malonaticus strains can utilize malonate. Malonate utilization is an important differential trait and well recognized as being possessed by six of the seven Cronobacter species. Interestingly, Alsonosi et al. found that $33 \%$ of the 51 Cronobacter hospital-related cases (17/51, irrespective of age) were caused by C. malonaticus and came from sputum samples in 13 of the 17 cases [15]. These data suggest that $C$. malonaticus may have a greater epidemiological significance with respiratory infections than what was previously thought. The sequence type for these strains was determined to be ST7. Querying the Cronobacter MLST website (Available online: https://pubmlst.org/cronobacter/, last accessed 12/20/2019) for which C. malonaticus STs were involved in clinical cases showed a predominance of ST7 strains $(34 / 69,49 \%)$ or related strains that were associated with CC7 $(41 / 69,59 \%)$ followed by strains identified as ST11, ST60, ST307, and ST84 to name a few of the other noted STs [60]. The fact that 12 of these 17 cases (70\%) reported by these authors involved infections associated with individuals of 5 years or older, also supports the fact that $C$. malonaticus may be emerging as a pathogen of older children and the elderly $[15,65]$. Interestingly, Iversen et al. [1], reported that malonate utilization was present in approximately $5 \%$ of $C$. sakazakii strains. Subsequently, using in parallel a novel DNA microarray and whole genome sequencing analyses to identify Cronobacter species Gopinath et al. described a nine gene malonate operon ( $7.7 \mathrm{kbp}$ in size) that was located between two highly conserved flanking genes, gyrB and kat $G$ in ST64 C. sakazakii strains obtained from clinical sources, foods and food production facilities in Europe, southern Asia, China, and USA [68]. Of note, the presence of gyrB and kat $G$ was also found to be conserved among all Cronobacter species even malonate-negative C. sakazakii strains of other STs; however, instead of the malonate utilization gene cluster, there is a 323-325 bp nucleotide region [68]. The under appreciation of malonate-positive C. sakazakii strains that are associated with foods presents an epidemiological 
problem if phenotypic identification schemes alone are used in species identity. However, to date, it is unknown whether other C. sakazakii STs possess a malonate utilization operon or if this genotype is exclusively found in C. sakazakii ST64 strains.

Based on WGS studies by Ogrodzki and Forsythe, an important capsular typing scheme using the $\mathrm{K}$-antigen and colanic acid (CA) biosynthesis regions was described [69]. It is based on information coming from analyzing 104 Cronobacter strains for the presence of a previously uncharacterized Cronobacter capsular region ( $k p s)$ [69]. The region was like the well-described K-antigen gene cluster of Escherichia coli. The gene cluster is comprised of three regions: K-antigen region 1 (kpsEDCS) and region 3 ( $k p s T M)$ are conserved across the genus, and there are two variants of region 2 that was found. Genes associated with K-antigen type 1 are present in all seven species of Cronobacter. However, the prevalence and distribution of K-antigen type 2 (specifically of interest is the capsular profile $\mathrm{K}$-antigen gene cluster 2-colanic acid gene cluster 2-cellulose positive profile) are not as prevalent in all seven species for this antigenic profile is found only in C. sakazakii, C. malonaticus, C. turicensis, and C. dublinensis. It is thought that the presence of this capsular type specifically in C. sakazakii and C. malonaticus strains may confer a favorable phenotype important in desiccation resistance, persistence, and serum resistance as well as increased macrophage survival, resulting in a more physiologically fit pathogen [69].

\section{Cronobacter turicensis}

Cronobacter turicensis, as described by Iversen et al. [1], comprises strains which were previously reported by Farmer et al. [59] as belonging to biogroup 16 of the former E. sakazakii species epithet [1,70]. Much less is known about this species, the first clinical case of $C$. turicensis infection was reported in 2005 by Stephan et al. [52] as a strain that caused the death of two neonates in 2005. Querying the Cronobacter MLST website (Available online: https://pubmlst.org/cronobacter, last accessed 12/20/2019) for C. turicensis STs involved in clinical cases showed that there were only 10 strains which came from clinical cases and these cases involved strains possessing the following STs: ST5, ST19, ST309, ST350, and ST636 determinants and seven of these ten strains came from Europe [60]. However, there were 100 C. turicensis records registered in the Cronobacter MLST site which were obtained from a variety of sources including milk powder, water, spices, tea, vegetables, insects, manufacturing environments, and ready to eat foods, with multiple ST designations.

\section{Cronobacter Secreted Toxins/Exoproteins}

\subsection{Cronobacter Plasminogen Activator}

Whole genome sequencing studies of $C$. sakazakii BAA-894 demonstrated the presence of plasmid pESA3 [33] and in silico analysis showed that it encodes an outer membrane protease with significant amino acid sequence homology to proteins belonging to the omptin family [47,71]. Omptins are outer membrane proteins which are expressed by several members of the Enterobacteriaceae [72,73]. Omptins are known bacterial virulence factors that can function as proteases, adhesins, or invasins [72-74]. Franco et al. [47] showed that this plasmid-borne OmptinT-like protease now named Cronobacter plasminogen activator (Cpa) had significant identity to proteases that belong to the Pla subfamily of omptins such as PgtE which is expressed by Salmonella enterica [71]. Other omptin-like proteases include Pla of Yersinia pestis, and PlaA of Erwinia spp. Figure 2 shows the phylogenetic relatedness among the OmptinT family of proteins including the phylogenetic relatedness of Cpa possessed by C. sakazakii and C. universalis which is also mapped to plasmid pCUNV1. Furthermore, Franco et al. summarized the proteolytic activity of members of this subfamily of proteases and showed that Cpa expressed by $C$. sakazakii degraded several host serum proteins, including circulating complement components [71]. It is conjectured that the degradation of these complement components by Cpa will allow systemically circulating Cronobacter cells to be protected from complement-dependent serum killing. Moreover, Cpa like other Pla-like proteins is thought to cause unrestrained plasmin activation by transforming 
plasminogen to plasmin, and inactivation of plasmin inhibitor $\alpha 2$-antiplasmin $(\alpha 2$-AP). Together, these findings suggest that Cpa expressed by $C$. sakazakii could proteolytically cleave complement components $\mathrm{C} 3, \mathrm{C} 3 \mathrm{a}$, and $\mathrm{C} 4 \mathrm{~b}$ and cause rapid activation of plasminogen and inactivation of $\alpha 2-\mathrm{AP}$. Figure 3 shows schematically how Cpa may interact with plasminogen and $\alpha 2$-AP causing plasminogen to be continuously converted to plasmin which then allows for uncontrolled degradation of fibrin clots and extracellular matrix proteins which will further promote systemic spread of the pathogen. These results suggest that $\mathrm{Cpa}$ is an important virulence factor involved in serum resistance, as well as in the systemic spread of C. sakazakii. Unlike Pla (expressed by Y. pestis), it is not known whether plasmin binds to the Cronobacter bacterial cell surface, but it is known that similar plasma proteins such as fibronectin binds to the Cronobacter bacterial surface [75]. The presence of cpa (pESA3p05434) encoded on pESA3-like plasmids was thought to have evolved from a prototypical plasmid backbone through the co-integration or deletion of virulence determinants in each of the Cronobacter species. The cpa gene in C. sakazakii strain BAA-894 was found to be flanked upstream by an MFS transporter homologue and downstream by $c p m J K$, encoding proteins potentially involved in carbapenem resistance [47]. Interestingly, the cpa-flanking regions on plasmid pESA3 are maintained on plasmid pCTU1, the virulence plasmid harbored by C. turicensis; however, instead of the 1427-bp nucleotide region containing cpa, plasmid pCTU1 has a unique 37-bp region [47]. Furthermore, noted regulatory features that were found associated with this genomic region are palindromic inverted repeats (10-13 nucleotides in size which are separated by a 10-bp spacer). Furthermore, Franco et al. showed that the conserved plasmid pCTU1 region is located upstream of this inverted repeat, while the cpa locus on plasmid pESA3 is located downstream [47]. These authors hypothesized that the inverted repeat is a transposon attachment site, which would explain the acquisition, evolution, and presence of $c p a$ on pESA3 or its absence on pCTU1. Taken together, these results suggest that these virulence plasmids have undergone microevolution or the co-integration or deletion of plasmid genetic attributes, which potentially may continue leading to the acquisition (or deletion) of other virulence genes. Furthermore, PCR analysis using primers designed to detect cpa showed that most (173/177, 98\%) C. sakazakii do harbor cpa [47]. In addition, two C. universalis strains were also PCR-positive for cpa. Strains of the other Cronobacter species were PCR-negative for $c p a$, providing evolutionary evidence that the cpa locus may be a species-specific locus for $C$. sakazakii and C. universalis. Furthermore, Eshwar et al. examined a C. sakazakii mutant (ATCC BAA-894 $\Delta c p a$ ) deficient in cpa and compared its virulence with the wild type strain BAA-894 and complemented strain ATCC BAA-894 $\triangle$ cpa/pQE30::cpa (with cpa in trans) in the Zebrafish infection model [76]. The cpa-deficient mutant (C. sakazakii ATCC BAA- $894 \Delta c p a$ ) exhibited a $10 \%$ mortality rate compared to an $80 \%$ mortality rate with the wild type parental strain (ATCC BAA-894). Additionally, virulence was partially restored (40\% mortality rate) with the complemented strain. Interestingly, growth of these strains in the zebrafish embryo model over time showed that until $24 \mathrm{~h}$ post infection (hpi), the growth slowed in the mutant followed by a sharp drop in bacterial counts of the mutant at $48 \mathrm{hpi}$, suggesting that the embryos could eliminate the cpa mutant strain by that time point [76]. Of note, ST8 C. sakazakii strains which possess the pESA3 virulence plasmid such as the clinical C. sakazakii species type strain ATCC $29544^{\mathrm{T}}$ do not possess cpa, yet this strain is extremely virulent. These results suggest that other factors besides cpa are responsible for illness. 


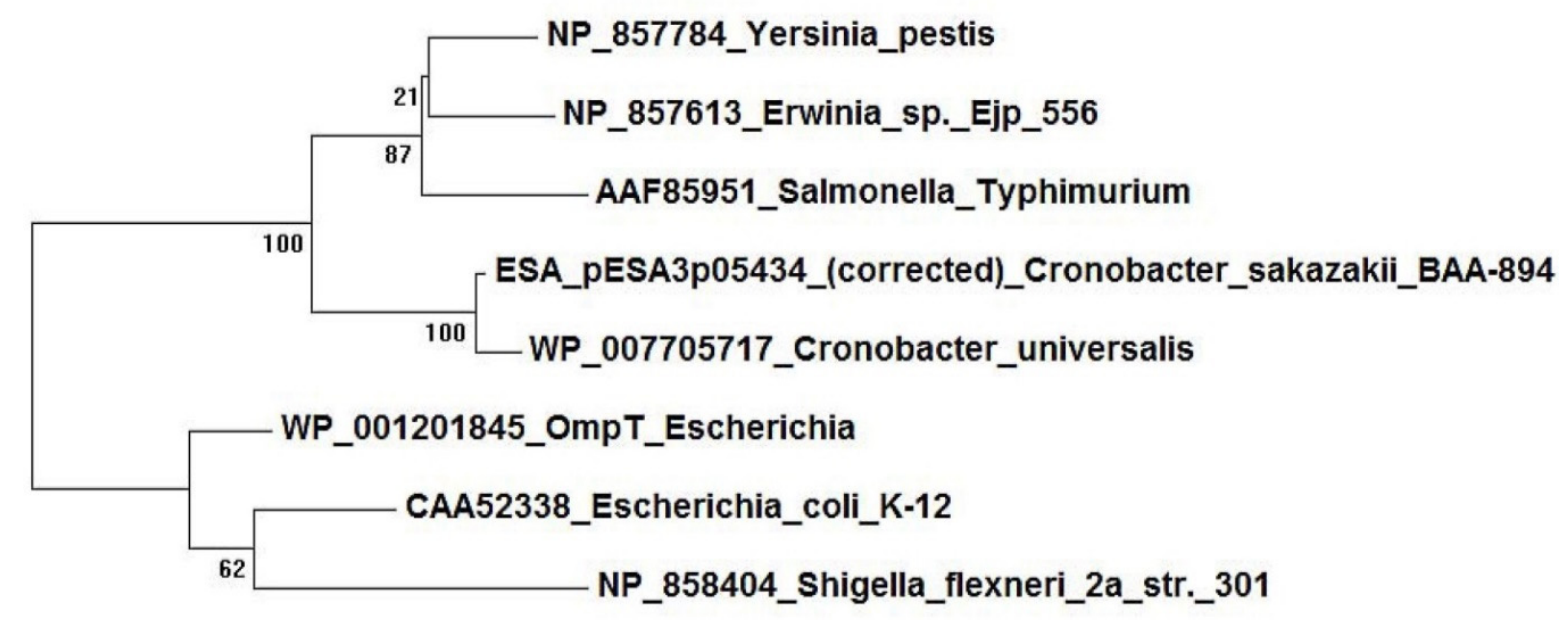

0.10

Figure 2. Phylogenetic tree of the homologs of omptin, Cpa. The NCBI accession numbers of the proteins sequences used in the figure are as follows: Yersinia pestis, Pla (plasminogen activator, NP_857784); S. enterica Typhimirium, PgtE (outer membrane serine protease, AAF85951); Erwinia, PlaA (plasmid, NP_857613); C. sakazakii BAA-894, Cpa (plasmid, ESA_pESA3p05434); C. universalis NCTC 9529, Cpa (omptin family outer membrane protease, WP_007705717); E. coli, OmpT (outer membrane protease VII, AP_001210); E. coli, OmpP (outer membrane protease P, X74278); and Shigella flexneri, SopA (outer membrane protease, NP_858404). Forty-one amino acids were added to C. sakazakii Cpa protein in its $\mathrm{N}$-terminal to correct the incomplete annotation of the protein in the GenBank record. The MUSCLE algorithm of the MEGA7 suite was used for multiple sequence alignment. Phylogenetic analyses were conducted in MEGA7 using the Maximum-Likelihood algorithm [77]. Three hundred nine amino acid positions across the protein were used for determining the distance between the homologs in the tree. Bar marker represents 0.1 amino acid differences. Confidence values given in the nodes were derived out of bootstrap test consisting of 500 iterations. 


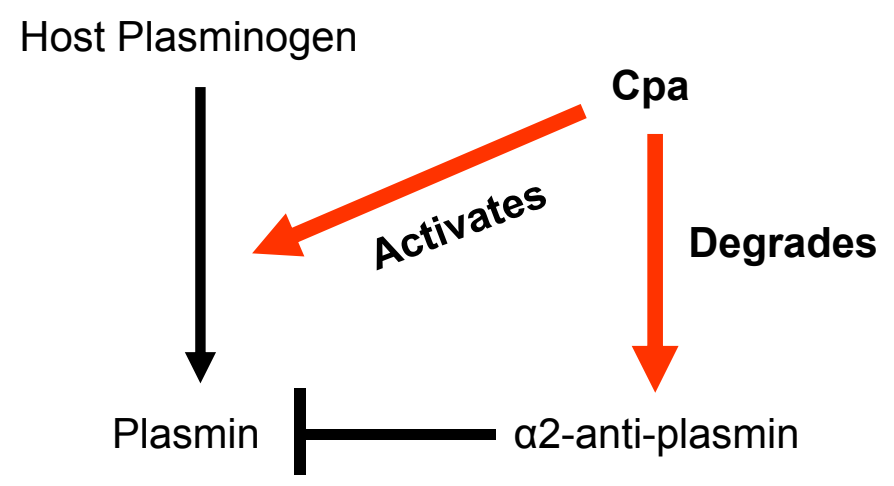

1

Uncontrolled fibrinolysis of

fibrin-extracellular matrix proteins

Figure 3. Mechanisms of plasminogen activation by C. sakazakii and its role in bacterial virulence. It is thought that a complex with plasminogen is formed when Cronobacter plasminogen activator (Cpa) is expressed by invasive C. sakazakii (cells invading a host's circulatory system), which causes proteolysis and conversion of host plasminogen to plasmin. Plasmin bound (conjecture) to bacterial cell surfaces then catalyzes the degradation of fibrin polymers (fibrinolysis) which are major components of fibrin clots and the extracellular matrix. Additionally, Cpa can also inactivate $\alpha 2$-anti-plasmin which normally would break down plasmin. Thus, there is an unlimited activation of plasmin leading to increased fibrinolysis which in turns allows for increased invasiveness.

\subsection{Zinc Metalloprotease}

Many pathogens produce bacterial metalloproteases which require basal metal ions such as zinc for catalytic activity and are thought to play a role in virulence in a variety of animal and plant hosts [78]. For example, the metalloprotease expressed by Vibrio vulnificus (designated VVP) causes serious hemorrhagic skin destruction through the breakdown of vascular extracellular matrices (e.g., endothelial basement membranes), and are especially active towards basal lamina-based type IV collagen fibers that form the scaffold and structural membrane support of cells [79]. V. vulnificus VVP also causes fluid accumulation or edema in tissues through induction of exocytotic histamine release from mast cells and/or activation of the factor XII-plasma kallikrein-kinin cascade [80]. These metalloproteases have both enzymatic and host immune modulation activities. Metalloproteases can also disassociate iron from heme that is complexed with specific host serum protein carriers [81]. They can degrade other plasma proteins and target tissue membrane proteins involved in cellular invasion, meningitis, and periodontal disease [81]. It is also thought that metalloproteases cause destruction of endothelial cell membranes which are associated with capillary vessels which lead to leakage of blood components into surrounding tissues, thereby enhancing the dissemination of bacteria from entry sites of infection into systemic circulation and being finally translocated to a target tissue site such as the blood-brain barrier (BBB) [81,82]. Kothary et al. described a zinc-containing metalloprotease (Zpx) expressed by Cronobacter species and showed that Zpx caused rounding (and eventual cell membrane damage) of Chinese Hamster ovary (CHO) cells [83]. Results showed that the proteolytic activity was cell surface-associated and that the metalloprotease is not secreted well. Even though these authors found that Zpx shares significant homology with other bacterial metalloproteases; 
an indispensable motif which is required for secretion of proteins was not found for Zpx. Nonetheless, these results support the finding that the protease may be cell bound. Interestingly, the observation that the metalloprotease may be cell bound suggests that an intimate bacteria-to-host cell contact may be required for initiation of its cytopathic effects through degradation of soluble proteins [83]. Further studies by this group showed that zpx was present in all Cronobacter species examined and that it possessed collagenolytic activity, but not elastinolytic activity [76,84]. The role of this protease in disease may be its involvement in necrosis and cellular damage in neonates with necrotizing enterocolitis; it may also be responsible for the pathology seen in meningitis [85]. Using the zebrafish embryo model, Eshwar et al. showed that the virulence of a C. turicensis LMG $23827^{\mathrm{T}} \Delta z p x$ mutant was diminished by $60 \%$ and virulence was restored to a large extent $(80 \%)$ in experiments using a complemented mutant [84]. In another study, Eshwar et al. showed that the matrix metallopeptidase 9 (MMP-9), a eukaryotic proteinase which cleaves extracellular proteins such as collagen, was the substrate for Zpx and that this metallo-enzyme induces the expression of MMP-9 and led to a yet-undescribed mutual cross-talk between two proteases of bacterial and a host origins [84].

\subsection{Hemolysins}

A hemolysin (hly) gene was identified as a hemolysin III homolog (COG1272) by Cruz et al. [86]. Since then, several investigators have predicted that all Cronobacter species may possess a hemolysin III homolog (COG1272) [30,49,80]. However, strains identified to the species level (reported as E. sakazakii) by using $16 \mathrm{~S}$ rRNA gene sequences and PCR designed to target the hemolysin III homolog gene showed that some strains possessed the gene, while others did not [86]. Singh et al. characterized the beta-hemolytic activity of several C. sakazakii strains isolated from food, soil, and water; these strains were PCR-positive for the COG1272 gene [87]. To better appreciate the gene prevalence, distribution, and phylogenetic relatedness of hemolysin III homolog COG1272 gene, Jang et al. [88] performed PCR, microarray and WGS analyses on over 300 Cronobacter strains of all seven species with their identities confirmed using both the rpoB and $c g c A$ species-specific PCR assays as described by Stoop et al. [89], Lehner et al. [90] and Carter et al. [91], and showed that they do possess a hemolysin III COG1272 gene homolog, but the PCR primers described by Cruz et al. [86] may not detect all COG1272 orthologues in every Cronobacter species uniformly. Additionally, three other hemolysin genes were described by using this parallel next generation DNA-based approach and include alleles for a cystathionine beta synthase (CBS) domain containing hemolysin, a putative hemolysin, and a 21-kDa hemolysin [88]. Furthermore, Umeda et al. recently reported that 57 Cronobacter strains showed $\beta$-hemolytic activity against guinea pig, horse, and rabbit erythrocytes [92]. However, using sheep erythrocytes, the majority of strains (53/57; 92.9\%) exhibited $\alpha$-hemolysis activity. Taken together, more in-depth genetic studies are needed to assign functionality of these various hemolysin genes to the corresponding phenotype.

\subsection{Enterotoxin}

The suckling mouse assay, as described by Richardson [93], is used to study diarrhea caused by enterotoxin activity of many enteric pathogens. To determine if Cronobacter species (identified as E. sakazakii) could cause fluid accumulation (a measure of enterotoxin production) in suckling mice, Pagotto et al. tested 18 isolates [85]. Four of the eighteen strains caused fluid accumulation, suggesting that these strains may produce an enterotoxin [85]. Raghav and Aggarwal purified a 66-kDa secreted exoprotein using ammonium sulfate precipitation, followed by DEAE-cellulose ion exchange and desalting with SephadexTM G-100 [94]. The authors then used the suckling mouse assay to follow the isolation of the enterotoxin in each purification step. Toxin activity was undetectable in toxin preparations heated at $100^{\circ} \mathrm{C}$ and held for $30 \mathrm{~min}$ but was somewhat stable at $90^{\circ} \mathrm{C}$ held for $30 \mathrm{~min}$ [94]. To date, no gene has been assigned to this protein. 


\subsection{Macrophage Infectivity Potentiator (FkpA)}

Internalization of invading pathogens by macrophages is an innate immune process and formulates a host's primary defense toward eliminating invasive pathogens. The capability of some pathogens to survive, persist, and multiply within macrophages is critical for their systemic survival, and as a primary step in development of severe illnesses such as sepsis or meningitis [32]. Studies by Horne et al. [95] and Humphreys et al. [96] suggest that the survival and persistence of Salmonella in murine and human macrophage cells may be affected by periplasmically located cis-trans prolyl isomerases (PPIases) such as Fkp. Cis-trans prolyl isomerases may be related to the mip (macrophage infectivity potentiator) gene [97]. Eshwar et al. queried GenBank for homologies of this gene in available Cronobacter genomes and found the presence of $f k p A$-like gene homologs in these organisms [97]. These authors evaluated the intracellular survival of FkpA variants in human macrophages by knocking out the $f k p A$ genes in C. turicensis and C. universalis. Even though macrophage survival and replication varied among Cronobacter strains due to the presence of amino acid sequence variations in the respective FkpA proteins, their results provided convincing evidence that FkpA must be considered a virulence factor. These results also show that FkpA is expressed and possibly released intracellularly within the macrophage [97].

\section{Bacterial Protein Secretion Systems in Cronobacter}

Through the span of evolutionary time, bacteria have developed highly specialized systems to transport and secrete small molecules, proteins, and DNA [98]. The secretion of these substrates play key roles in how bacteria respond to their environment and in several important host-associated biological activities such as adaption, adherence, pathogenicity, persistence, and survival. The eventual outcome of the secretion process allows intracellular substrates to either be released extracellularly into the environment, remain cell-surface associated, or they are secreted through specialized outwardly directed flagellum-like structures (called injectosomes) into an adjacent cell (of either eukaryotic or bacterial origins). Five secretion systems that function to passage proteins across the cell membrane and the Gram-negative cell wall/outer membrane (OM) have been described and are classified as follows: type 1 secretion system (T1SS), T2SS, T3SS, T4SS, and T6SS. Another secretion system called T5SS involves secretion though just the OM and includes assembly systems associated with type 1 fimbriae and curli. The secretion process triggers what seems to be a strictly regulated response and aids in the recognition by the bacterial cell of the presence of host receptors or other host proteins. As an overview, secretion systems described in this review will concentrate on those protein secretion systems carried by Cronobacter species and will illustrate their role in making a more physiologically fit pathogen through the secretion of toxins and other proteins. To date, Cronobacter species have been found to possess T1SS, T2SS, T4SS, T5SS, T6SS, but no T3SS have been found.

\subsection{Type 1 and 2 Secretion Systems}

In general, T1SSs of Gram-negative bacteria allow for the secretion of a variety of substrates which are directly delivered from the bacterial cytoplasm into the extracellular milieu. Examples of such proteins are HasA (amino acid Heme-binding protein A; pfam06438) a heme acquisition protein or hemophore expressed by Yersinia, Serratia, and Pseudomonas species and many hemolysins such as E. coli $\alpha$-hemolysin [98]. Due to their overall protein ultrastructure and homologies associated with multiple protein components, T1SSs are also closely related to the resistance-nodulation-division (RND) family of multidrug efflux pumps [92]. From structural and functional data, a simple secretion process for the T1SS and RND efflux pumps has been proposed [98]. Both systems form a tripartite double-membrane-spanning channel with an ATP-binding cassette transporter (ABC transporter) family protein which is also called an inner membrane component (IMC). Additionally, other proteins associated with the T1SS complex include a periplasmic adaptor protein (referred to as the membrane fusion protein) and TolC (an OM protein channel) common among Gram-negative 
bacteria [98]. The IMC component is involved in substrate recognition by identifying a glycine-rich motif (Gly-Gly-X-Gly-X-Asp) that is usually present as a repeat in the carboxyl terminus of its substrates, but as mentioned previously this motif is not found in the Zpx metalloprotease protein [83]. Presently functional studies of T1SS genes and their role in the secretion of toxins in Cronobacter are lacking. Another difference between T1SS and RND efflux pumps is that T1SS secretion is driven in an ATP-dependent manner, whereas secretion by RND efflux pumps uses a proton gradient connected to the secretion/uptake of respective substrates [98].

Type 2 secretion systems are also found in a wide variety of pathogenic and non-pathogenic bacteria. Several major differences exist between T2SSs and T1SS; T2SSs secrete folded proteins from the periplasm into the extracellular environment and are usually more complex than T1SS in that they are composed of 12-15 membrane spanning protein components [98]. Examples of T2SS proteins in other pathogens include hydrolyzing enzymes, such as pseudolysin of Pseudomonas aeruginosa, pullulanase of Klebsiella pneumoniae (that are important for host bacterial survival and growth within an environmental niche), and toxins (e.g., cholera toxin of V. cholerae) [98]. Two such Cronobacter proteins, thought to be secreted by a T2SS pathway, are the enzymes $\alpha$-glucosidase and $\beta$-cellobiosidase. These two enzymes are used in differentiating Cronobacter species from other Enterobacteriaceae family members and play a role in carbohydrate metabolism [1]. Another major difference between T2SS and T1SSs is that T2SSs contain a pseudopilus which is in contrast to other pili used in adherence; the T2SS pseudopilus remains confined within the bacterial cell's T2SS periplasmic secretome [92]. Similarly, type IV pili are evolutionarily related to the T2SS, and they share many similar structural and functional features [98].

\subsection{Type 4 Secretion System}

Type 4 secretion systems have the distinct ability among the various secretion systems to mediate the translocation of both DNA and proteins into bacterial and eukaryotic target cells through direct contact with a recipient cell. T4SSs are found in Gram-negative and Gram-positive bacteria and in some Archaea species [98]. Three categories of T4SS have been described; (i) conjugation systems which transfers DNA to recipient cells from donor cells by a contact-dependent process, (ii) T4SSs involved in pathogenicity by delivery of effector molecules or toxic proteins into eukaryotic host cells, and (iii) T4SSs involved in transfer of DNA to/or from the extracellular milieu [99]. Plasmid conjugation is mediated through a specific pilus structure. It is thought that certain bacteriophage uses T4SS pili as receptors [100]. Conjugation in bacteria is very common and the gene cluster responsible for T4SS secretion and pilus assembly are located on plasmids such as pESA2, SP291-2, and pCTU2 in Cronobacter $[27,33,47,52,53]$. However, there are some isolated genes located on the chromosome, but these are not in operonic form.

A second set of conjugative components include the "integrative and conjugative elements" (ICEs) That many bacteria possess. These are first excised from the chromosome of the donor cell, and then translocated to the recipient cell after a circular intermediate is formed. Once translocated, the ICE then reintegrates back into that cell's chromosome [101]. Grim et al. reported that both $C$. muytjensii and C. universalis possess an ICE; the ICE in C. muytjensii is found in Genomic region 27 [102]. In some bacterial pathogens such as Helicobacter pylori and Bordetella pertussis, T4SSs also deliver effector proteins into the cytoplasm of a host cell to support bacterial intracellular survival [98]. Some examples of T4SS gene clusters found in other enteric species include the Ti plasmid of Agrobacterium tumefaciens and the conjugative plasmid pKM101 and plasmid R388 of E. coli [98]. Examples of proteins secreted by T4SSs include the pertussis toxin and CagA of H. pylori [98]. The gene cluster for the Cronobacter T4SS consists of genes encoding 12 proteins (VirB1-B11 and VirD4) and is found on a plasmid pESA2/pCTU2 [33,47,52]. A survey for prevalence and distribution of the T4SS pEAS2-like plasmids (synonymous with pCTU2 and pSP291-2) among 570 Cronobacter strains representing the seven species is shown in Table 1. The T4SS containing plasmid is found in approximately $4 \%$ of the strains. It is interesting to speculate on the evolutionary significance of Cronobacter strains harboring a 
plasmid with T4SS loci in that it adds to other lines of evidence suggesting that the environmental origins and ancestral econiche for Cronobacter species may be with eukaryotic plants [103,104]. Presently, it remains unanswered why most Cronobacter species have lost this plasmid (Table 1).

Table 1. Comparison of prevalence and distribution of pESA3/pCTU1 (incFIB), pESA2/pCTU2 (incF2), and pCTU3 (incH1) plasmids among 570 Cronobacter isolates.

\begin{tabular}{|c|c|c|c|c|}
\hline \multirow{2}{*}{ Species } & \multirow{2}{*}{ No. of Isolates } & \multicolumn{3}{|c|}{$\begin{array}{l}\text { No. of Isolates with the Indicated Plasmid Incompatibility } \\
\text { Class (\%) a }\end{array}$} \\
\hline & & $\begin{array}{c}\text { pESA3/pCTU1 } \\
\text { (incFIB) }^{b}\end{array}$ & $\begin{array}{l}\text { pESA2/pCTU2 } \\
\text { (incF2) }\end{array}$ & $\begin{array}{l}\text { pCTU3 } \\
\text { (incH1) }\end{array}$ \\
\hline C. sakazakii & 507 & $493(97)$ & $20(4)$ & $142(28)$ \\
\hline C. malonaticus & 30 & $30(100)$ & $3(10)$ & $12(40)$ \\
\hline C. turicensis & 13 & $13(100)$ & $1(8)$ & $8(62)$ \\
\hline C. muytjensii & 12 & $9(75)$ & $0(0)$ & $1(8)$ \\
\hline C. dublinensis & 5 & $4(80)$ & $0(0)$ & $0(0)$ \\
\hline C. universalis & 2 & $2(100)$ & $0(0)$ & $1(50)$ \\
\hline C. condimenti & 1 & $1(100)$ & $0(0)$ & $0(0)$ \\
\hline Total & 570 & $552(97)$ & $24(4)$ & $164(28)$ \\
\hline
\end{tabular}

${ }^{a}$ Numbers within parentheses are the percentage PCR-positive for each plasmid replicon gene locus (repA) as described by Franco et al. [47]. The prevalence of pESA3/pCTU1 (incFIB), pESA2/pCTU2 (incF2), and pCTU3 (incH1) plasmids among the strains were calculated using the total number of strains tested. ${ }^{b}$ The column labelled pESA3/pCTU1 (incFIB) is also presented in Table 4 as well for ease of comparison of the prevalence and distribution among the three plasmid types of the seven Cronobacter.

\subsection{Type 5 Secretion System}

The Type 5 secretion system or "autotransporter secretion pathway" is a unique secretion mechanism, in which an autotransporter C-terminal domain forms a pore for the secretion of the $\mathrm{N}$ terminal domain of the protein through the cell wall/outer membrane [105]. The substrate first must enter the periplasmic space usually through the activity of a SecYEG translocon [98]. As described by Henderson et al. autotransporters can facilitate several virulence mechanisms, such as the expression of adhesins used to colonize host cells, and actin-promoted bacterial intracellular mobility [106]. Proteins secreted by T5SS pathways need to possess three important domains; (i) a N-terminal targeting motif (amino-terminal leader sequence) that functions as a signal peptide to mediate translocation across the inner membrane using a SecYEG translocon, (ii) a carboxy-terminal translocation domain that forms a beta-barrel pore allowing the protein to be secreted through the OM, and (iii) the secreted mature protein $[106,107]$. Recently, Kothary et al. showed that an autotransporter protein $(<100 \mathrm{kDa}$ in size) was captured as a protein component within outer membrane vesicles (OMVs) of C. sakazakii, C. malonaticus, and C. turicensis [108]. This outer membrane protein (OMP) and others packaged within OMVs by Cronobacter were also confirmed by Kothary et al. [108] using PCR and DNA microarray analyses. ics A, which is harbored on plasmid pWR100, the virulence plasmid of Shigella species, is well known to encode for an autotransporter protein and is responsible for the intracellular/intercellular bacterial movement of this pathogen through polar deposition of filamentous actin to bind to the bacterial cell surface [109].

Bioinformatically, Grim et al. also found several autotransporter secretion gene loci (single genes or pairs of genes within the core genome) of C. sakazakii strain BAA-894, C. malonaticus strain LMG23826T, C. turicensis LMG 23827T, C. dublinensis subsp. lactaridi LMG 23825T, C. dublinensis subsp. dublinensis LMG 23823T, C. dublinensis subsp. lausannensis LMG 23824T, C. muytjensii ATCC 51329T and C. universalis NCTC 9529T, within accessory genomic regions 21 and 121 [102].

\subsection{Type 6 Secretion System}

The Type 6 secretion system is a secretion system which translocates effector proteins into host cells or into the environmental milieu using an outwardly directed phage-like structure for the secretion. 
Many of the effector proteins such as Hcp1 (hemolysin co-regulated protein 1) and VgrG (valine-glycine repeat $G$ protein) are toxins that play a role in bacterial pathogenesis and environmental survival. This is accomplished through augmenting competition by subverting host-pathogen interactions away from pathogenesis and towards a more commensal or mutualistic state or it may mediate cooperative interactions between bacteria $[110,111]$. T6SS gene clusters have been found in many bacterial species [110]. Several T6SS gene clusters have been identified among the various Cronobacter species which are located both within the Cronobacter core genome as well as on a pESA3 virulence plasmid in C. sakazakii [47]. T6SSs are typically comprised of a conserved core gene cluster of up to 15 open reading frames (ORFs) [112]. Franco et al. reported in silico findings of a T6SS gene cluster consisting of 16 ORFs (ESA_pESA3p05491 to p05506) containing genes encoding for both Hcp1 and VgrG [47]. Other T6SS genetic components harbored on plasmid pESA3 included genes for IcmF-DotU/IcmH-SciN homologues which were found to share significant homology with T6SS stabilization proteins [112]. Additionally, within the plasmid pESA3 gene cluster is $c l p V$, whose ATPase activity is crucial for T6SS activity [110]. The T6SS gene cluster contained on plasmid pESA3 is flanked upstream by a $g h t R$-like homologue whose product is characterized as a transcriptional regulator [47]. Interestingly, downstream of the plasmid pESA3, T6SS gene cluster are composed of three putative genes encoding increased copper tolerance, such as $d s b G$ [47]. The pESA3 regions flanking the T6SS gene cluster are conserved on plasmid pCTU1; however, the C. sakazakii T6SS gene cluster is replaced instead with a specific 32-bp sequence region. Recently, Wang et al. showed that C. sakazakii strain 12868 possessed two T6SS systems [113]. Their results suggest that T6SS-1 may contribute to interbacterial species competition processes which may allow C. sakazakii to better compete with other species in particular niches and the second gene cluster (T6SS-2) may be important during host interaction. Much more information is still needed regarding T6SSs.

\section{Quorum Sensing Signaling Systems}

Biofilm formation and expression of virulence factors in many bacteria have been found to be mediated by quorum sensing (QS) mechanisms [36]. Quorum sensing is a physiological cell-to-cell communication system involving the synthesis, secretion and subsequent detection of signaling molecules of low molar mass $[36,114]$. Increased extracellular concentrations of these signalling molecules are detected by cells and upon reaching a population density-dependent threshold induces specific, targeted, and coordinated expression of genes [114-117]. In Gram-negative bacteria, several structurally unrelated signal molecules have been identified including $N$-acyl-homoserine lactones (AHLs), alkylquinolones, a-hydroxyketones, diketopiperazines (DKPs) and small diffusable signal factors (DSFs) mimicking fatty acid compounds $[30,118]$. For a comprehensive review on the synthesis and characteristics of these molecules please refer to the review by Hawver et al. [118].

In a study by Lehner et al., the ability of Cronobacter species (reported as E. sakazakii) to form AHLs was investigated on a set of biofilm forming isolates using ethyl actetate extracts of cell-free supernatants [35]. The results indicated the presence of two different types of AHLs (3-oxo-C6-HSL and 3-oxo-C8-HSL) in these organisms. Pinton et al. also detected short chain acyl-HSL in E. sakazakii isolated from raw milk using a bioassay with Chromobacterium violaceum [119]. However, in this early study, the respective signaling molecules were not chemically characterized in detail.

Da Silva Araujo et al. examined short chain acyl-HSLs produced by Cronobacter species (reported as E. sakazakii) isolated from a feeding bottle, using mass spectroscopy [120]. The three molecules that were identified included (S)- $N$-heptanoyl-HSL, (S)- $N$-dodecanoyl-HSL, and (S)- $N$-tetradecanoyl-HSL. In that same study, it was reported that Bacillus cereus was capable of secreting two exoproteins, an acyl-HSL lactonase and AHL acylases which resulted in depletion of the acyl-HSL secreted by Cronobacter species [120]. This interference in quorum sensing mechanisms, also known as quorum quenching, has been proposed as a promising alternative to control bacterial virulence. However, as observed in this later study, the depletion of the E. sakazakii acyl-HSLs by B. cereus extracelluar enzymes did not inhibit the growth or biofilm formation of E. sakazakii, suggesting the presence of alternative 
signaling molecules for both the E. sakazakii and the B. cereus QS and QS quenching systems or suggests that signaling is not critical in those assays.

Indeed, a very recent study showed that an alternative type of QS system exists, a cyclo (L-Pro-L-Leu) diketopiperazine was detected in pure and mixed cultures of C. sakazakii and B. cereus, possibly acting as cross-communication QS signals between these two organisms [121]. 2,5-DKPs are QS molecules commonly found in Gram-positive bacteria and are not usually secreted by Gram-negative microorganisms. However, previous studies showed that DKPs can modulate gene expression controlled by the expression of key regulatory proteins, substituting AHLs in a Gram-negative bacterium's QS scheme [122,123]. DKPs and short chain AHLs bind to the same regulatory protein allowing the co-sharing of an econiche by different microbial genera/species [123].

In 2016, Suppiger et al. reported that Cronobacter species secreted a diffusable signal factor (DFS) which was synthesized by DFS-type quorum sensing system [39]. Expression of this system was involved in the regulation of several phenotypes, including biofilm formation, colony morphology and swarming motility. Knock-out mutants of the sensing (RpfF) and the responding (RpfR) signal coding genes in $C$. turicensis strains were used in a Zebrafish embryo model and it showed a role of this regulatory system in the virulence of $C$. turicensis [39]. In addition, the study provided evidence that the $\mathrm{RpfF} / \mathrm{R}$ system modulates the intracellular cyclic-di-GMP levels within the organism, indicating that this secondary messenger is important in virulence and in regulating the expression of the above phenotypes.

In another recent study, long chain AHLs (C6-C18 in length) were identified and chemically characterized in C. sakazakii $[124,125]$. In vitro results demonstrated that these AHLs appeared sufficient to be detected after $6 \mathrm{~h}$ of incubation [126]. These authors showed that strains, which secreted significant levels of these AHLs, also produced significantly more extra-cellular polysaccharides (EPS) and formed more biofilms [126]. Unfortunately, data on the global regulatory circuitry that may be involved or other pleotropic effects possibly triggered through this QS system were not provided in this study [126].

In order to obtain a more comprehensive picture of the genes, secreted exoproteins, and regulatory mechanisms of these cell-to-cell communication systems, a more global approach such as transcriptomic or proteomic analyses are warranted. Such studies will identify possible secreted exoproteins in Cronobacter species that may also act as toxins. In addition, secreted exoprotein molecules that interfere with QS signaling may also provide an alternative approach to control Cronobacter organisms in dairy food production environments, as well as in disease. Though knowledge of how QS fundamentally controls Cronobacter virulence is in its early stages, some inferences can be made based on known common themes of QS regulation, such as the LuxR/SmcR regulatory schemes found among Vibrio species [125].

\section{Outer Membrane Proteins (OMPs)}

Although the genetic, genomics, and transcriptomics of Cronobacter pathogenesis has not been fully understood, a greater amount of information has been collected about several virulence factors, such as toxins, and putative genetic loci that may contribute to pathogenesis. Two well characterized outer membrane-related virulence genes, отрA and $о т p X$ (encoding for outer membrane proteins $A$ and $X$ ) are involved in adherence, invasion of intestinal cell epithelial, and brain endothelial cells through bacterial cell binding of host fibronectin [75]. Kothary et al. showed that both OmpA and OmpX are packaged within OMVs, which are expressed in stationary phased-grown cells of $C$. sakazakii, C. malonaticus and C. turicensis [108]. Ye et al. showed that the expression of these OMPs were greater in a virulent $C$. sakazakii strain than that of an avirulent strain [127]. Kothary et al. also found that other OMPs were packaged within secreted OMVs and include MipA (peptidoglycan synthesis), porin proteins (OmpC, OmpE, and OmpF), a conjugative plasmid-T4SS protein (CTP), a chaperonin (GroEL), and the previously mentioned OM autotransporter protein (OMATP) [93]. It is thought that these OMPs were packaged in a purposeful way and not randomly, and since the cells used to harvest the OMVs were in stationary phase of growth, these OMPs represent proteins expressed by cells grown 
under stress. Furthermore, parallel PCR and microarray analyses of 240 strains representing the seven Cronobacter species showed that these OMPs are highly conserved among all the species [108]. OMVs were once thought to be cellular artifacts, but currently, OMVs are now acknowledged structures possessing very diverse functions and are currently regarded as a protein secretion system used by bacteria to communicate with host cells and other bacterial cells. In addition to OMPs, Kothary et al. also showed that these OMVs contained substantial amounts of LPS [108]. The existence of LPS components in PIF has been known [128] and may lead to a situation where the LPS in PIF causes an unrestrained pro-inflammatory response in a susceptible host which could lead to a fatal "cytokine storm". It was shown by Townsend et al. [128] that the presence of LPS along with C. sakazakii in infant formula augmented the translocation of $C$. sakazakii from the rat gut lumen to the meninges through translocation of the blood-brain-barrier. One explanation is that the permeability of the host barrier to the pathogen was increased through disruption of cellular tight junctions by LPS [32]. More information is required to extend our understanding of the process regulating the production of OMVs and associated OMPs and their roles in disease.

\section{Exoproteins Involved in Osmotic Stress Response}

It is thought that the Cronobacter genus split from its most recent Enterobacteriaceae ancestor approximately 45-68 million years ago. This time period coincides with the Paleogene period of the Cenozoic era when early flowering plants were also evolving, thus supporting the theory that plants may be the ancestral habitat for Cronobacter species [56,103,129,130]. Recently, Afridi et al. provided evidence that plants inoculated with C. sakazakii (producing 1-aminocyclopropane-1-carboxylate deaminase, ACC deaminase) enhanced plant growth and saline stress tolerance [131]. It was concluded that ACC utilization by C. sakazakii promoted plant growth due to the lowering of excess ethylene production under salt stress. Additionally, it has been reported that Cronobacter have been isolated from flies [24]; thus, it is conceivable that the feeding of insect larvae on plants could have led to colonization of the fly and subsequent host adaptation and the further evolution of the genus [30]. Interestingly, Kocuria rhizophila, another ACC producing bacterium was isolated from the gut of pine lappet moth (Kunugia latipennis) [131]. During the Cenozoic era, it is also thought that Cronobacter species acquired the capacity to endure low-moisture environments thereby contributing to increased survival and persistence in low water activity food matrices and in their associated production environments. Little is known about how Cronobacter survive and persist in these low-moisture environments. Therefore, a complete understanding of stress adaptation is imperative to facilitate the design of strategies to mitigate its survival in PIF and other low-moisture food matrices. Bacterial osmotic stress responses (e.g., growth of cells in varied physiological environments of extreme salinity and/or osmolarity) are complex and involves both primary and secondary responses [132-134]. These cellular responses must be interpreted as a distinct sequence of cellular events, which have been well characterized in $E$. coli [132]. Generally, exposure of cells to high external osmolar growth conditions causes an efflux of water from the cell interior, resulting in a reduction of turgor pressure. Furthermore, an increase in the concentrations of intracellular metabolites and ions occurs. This is counterweighed by active potassium efflux and glutamate synthesis (the mainstay of the primary response) to restore intracellular water levels and, finally the potassium/glutamate is replaced with the accumulation of osmoprotectants, which is more compatible with cell growth ("compatible solutes", a hallmark of the secondary response). In addition, high osmolarity growth conditions cause a rapid increase in negative DNA supercoiling, which may control transcription of osmoregulated genes such as the induction of enzymes needed for the elimination of oxygen radical species in response to heat or osmotic shock [133]. Riedel and Lehner revealed that expression of most of the proteins, that were upregulated in cells (C. sakazakii strain 236) grown under desiccation stress, were either outer membrane proteins (e.g., OmpC and A) or proteins involved in transport of inorganic ions and energy production such as ATPases [133]. Other proteins found included Clp, chaperonin GroES (chaperones), Gln-binding periplasmic protein that are involved in amino acid transport and metabolism, an enolase, the PTS system, a glucose-specific IIA component, 
$\alpha$-Glucosidase (carbohydrate transport and metabolism), and inorganic pyrophosphatase (energy production and conversion) [133]. Interestingly, Feeney and Sleator also described a comparative genomic approach to investigate the ability of C. sakazakii to survive and persist under low water activity growth conditions [132] and these authors identified fifty-three genes that were involved in osmotolerance, including those associated with both hyper- and hypo-osmotic stress response systems. Various homologues of the principal osmotolerance genes of E. coli were also found; however, a key difference noted between C. sakazakii and E. coli was that C. sakazakii contained multiple copies of proP (seven) and two copies of opuC, which is involved in carnitine uptake, and has also been found to transport other osmoprotectants or solutes such as glycine betaine, proline, ectoine and choline [132]. Furthermore, it was noted that the osmotic stress response of $C$. sakazakii appeared to be regulated at the transcriptional, translational and post-translational levels, and these researchers suggested that RpoS most likely be functioning as a global transcriptional regulator involved in the osmotolerance response. A recent report describing RNA-sequence data obtained from cells of desiccated C. sakazakii strain SP291 shows that about $25 \%$ of the total C. sakazakii genes were significantly up-regulated and $10 \%$ of the genome were down-regulated [134]. qRT-PCR analysis demonstrated that the primary desiccation response involved the rapid accumulation of potassium glutamate to provide temporary protection against desiccation stress by immediately increasing the internal osmotic pressure of the bacterial cell [134]. This response was gradually downregulated over time while the secondary response was found in desiccated SP291 cells to remain constitutively up-regulated throughout the experiment. The trehalose biosynthetic pathway encoded by ots $A$ and ots $B$, are prominent secondary participants and were highly up-regulated in these desiccated C. sakazakii cells. Knockout mutants (deleted in ots $A B$ ) yielded considerable inhibition of desiccation survival compared to the isogenic wild type, confirming the physiological significance of trehalose in desiccation survival, but survival was not absolutely abolished, signifying that other unknown factors may be involved in the response to desiccation [134].

Besides the ability to tolerate, persist, and survive under high osmotic stress, Cronobacter have also adapted quite well to exposure to high growth temperature conditions $[23,135]$. Additionally, Williams et al. identified a hypothetical protein in several highly heat-tolerant Cronobacter strains which shared sequence homology with a protein found in the thermal tolerant bacterium, Methylobacillus flagellatus KT [136]. Furthermore, Gajdosova et al. [137] described an 18-kbp gene region that contained a cluster of genes, including a thermal tolerance protein described by Williams et al. [136] that had significant homology with other known bacterial proteins involved in many types of stress responses including heat, oxidation and acid stress. This island (called TPQLC or LHR) is found on the chromosome but appears to be horizontally acquired as it is flanked by transposases. However, not every strain that possesses a thermotolerant phenotype was found to possess this gene cluster [138], suggesting that other molecular mechanisms of thermotolerance exists. Yan et al. also found that C. sakazakii strain SP291 did not possess the M. flagellatus KT thermotolerance marker [138]. However, SP291 does have a shortened version of the TPQLC/LHR island $(\sim 6.5 \mathrm{~kb})$ [138]. More importantly, the truncated SP291 TPQLC/LHR island encodes the small heat shock protein and ClpG, which has been identified as the main source of heat resistance. Furthermore, Mercer et al. found evidence that the LHR island and its heat resistance function is conserved in many Enterobacteriaceae members [139].

\section{Efflux Pumps}

Efflux or transport of molecules across the Gram-negative bacterial cell envelope can be achieved in a single energy-coupled step. This "transport apparatus", is called an efflux pump (EP), which allows for nonstop passage of molecules across both inner and outer membranes and the intervening periplasmic space (does not generate periplasmic intermediates). In contrast to EPs, other protein secretion processes involve step-wise translocation through the inner cell membrane and the outer cell envelope via the periplasmic space [140]. Efflux pumps also can interact with different translocase complexes, depending on the transported substrate, so that these protein complexes provide the cell a greater functional diversity in secretion. In fact, many of these efflux pumps are multidrug transport 
efflux systems and many interconnect with other OMPs such as TolC, which belongs to a family of OMPs found in all Gram-negative bacteria. These proteins are essential for the expulsion of a plethora of compounds such as potentially small lethal agents, such as detergents, solvents, heavy metals and antibiotics [140]. In addition, there is accumulating evidence that efflux pumps that confer clinically relevant antibiotic resistance are also important in virulence; for example, the phytopathogen, Ralstonia solanacearum causes wilt disease in tomatoes [141]. In this study, mutants deficient in acrA and dinF genes, were significantly less virulent to tomato plants than the wild type strain. Another example of efflux pumps contributing to bacterial virulence is with Vibrio cholerae, the etiological agent of cholera. $V$. cholerae El Tor strain N16961 possesses six genes encoding for resistance-nodulation-division (RND) efflux pumps [142]. Mutants deficient in these efflux pump genes, including an RND-null strain, produced significantly less cholera toxin and fewer toxin-co-regulated pili than the wild type strain and was unable to colonize the infant mouse [142]. It was also found that a decreased virulence factor production in the RND-null strain was also linked to reduced transcription of tcpP and toxT, two membrane-associated transcriptional activators which directly activate transcription of the cholera toxin and toxin-coregulated pilus genes [142].

Negrete et al. found 13 different families of efflux pumps (shown in Table 3) among the seven Cronobacter species [143]. These efflux pumps were found associated with specific genomic regions (GR) such as gene clusters involved in sugar transportation, heavy metal efflux systems (Arsenic, copper efflux on plasmids pSP291-2, pCS2, and pCTU3). Interestingly, searching the chromosome of C. sakazakii strain BAA-894, 24 efflux-related genes were found that encode for RND efflux pump proteins involved in the transport of multidrug, and copper efflux (CusA/CzcA family heavy metal efflux), a MATE family efflux transporter, MFS Transport (EmrB and Bcr/CflA), glutathione-regulated potassium-efflux (KefC, KefF, KefG, and KefB) to name a few efflux systems [143]. Two efflux genes encoding for an efflux RND transporter periplasmic adaptor subunit and an arsenical efflux pump membrane protein ArsB, were found located on the virulence plasmid, pESA3 [143]. 
Table 2. Prevalence and distribution and NCBI protein annotations of efflux pump associated genes among the seven Cronobacter species as described on the pan-genomic Cronobacter microarray ${ }^{a}$.

\begin{tabular}{|c|c|c|c|c|c|c|c|c|c|}
\hline Family & Sub-Cluster & $\begin{array}{c}\text { NCBI } \\
\text { Efflux Protein }\end{array}$ & C. sak & C. tur & C. $d u b$ & C.con & C. mal & C. muy & C. uni \\
\hline \multirow{10}{*}{ Kef } & $\begin{array}{l}\text { Potassium efflux system KefA protein / Small-conductance } \\
\text { mechanosensitive channel }\end{array}$ & ABU75471 & + & + & + & + & + & + & + \\
\hline & $\begin{array}{l}\text { Potassium efflux system KefA protein / Small-conductance } \\
\text { mechanosensitive channel }\end{array}$ & ABU77777 & + & + & + & + & + & + & + \\
\hline & $\begin{array}{l}\text { Potassium efflux system KefA protein / Small-conductance } \\
\text { mechanosensitive channel }\end{array}$ & ABU78035 & + & + & + & + & + & + & + \\
\hline & Glutathione-regulated potassium-efflux system protein KefB & ABU79568 & + & + & + & + & + & + & + \\
\hline & Glutathione-regulated potassium-efflux system protein KefC & ABU78514 & + & + & + & + & + & + & + \\
\hline & Glutathione-regulated potassium-efflux system ancillary protein KefF & ABU78515 & + & + & + & + & + & + & + \\
\hline & Glutathione-regulated potassium-efflux system ancillary protein KefG & ABU75563 & + & + & + & + & + & + & + \\
\hline & Glutathione-regulated potassium-efflux system ancillary protein KefG & ABU79567 & + & + & + & + & + & + & + \\
\hline & Glutathione-regulated potassium-efflux system ATP-binding protein & ABU76397 & + & + & + & + & + & + & + \\
\hline & $\begin{array}{l}\text { Putative metal-binding cytoplasmic protein probably associated with } \\
\text { glutathione-regulated potassium-efflux }\end{array}$ & ABU79569 & + & + & + & - & + & + & + \\
\hline \multirow{7}{*}{ RND } & Membrane fusion protein of RND family multidrug efflux pump & ABU78037 & + & + & + & + & + & + & + \\
\hline & Membrane fusion protein of RND family multidrug efflux pump & ABU78865 & + & + & + & + & + & + & + \\
\hline & Probable RND efflux membrane fusion protein & ABU76411 & + & + & + & + & + & + & + \\
\hline & Cation efflux system protein CusC precursor & ABU79419 & + & + & - & - & + & - & - \\
\hline & Cobalt-zinc-cadmium resistance protein / heavy metal efflux pump, & & & & & & & & \\
\hline & CzcA family & ABU79422 & + & + & - & - & + & - & - \\
\hline & Cation efflux system protein CusF precursor & ABU79420 & + & + & - & - & + & - & - \\
\hline \multirow{2}{*}{ Threonine } & Putative threonine efflux protein & ABU75741 & + & + & + & - & + & + & + \\
\hline & Threonine efflux protein & ABU78513 & + & + & + & + & + & + & + \\
\hline PET & Putative efflux (PET) family inner membrane protein YccS & ABU77634 & + & + & + & + & + & + & + \\
\hline \multirow{2}{*}{$\begin{array}{l}\text { TetR } \\
\text { (AcrR) }\end{array}$} & $\begin{array}{l}\text { Transcription repressor of multidrug efflux pump acrAB TetR (AcrR) } \\
\text { family }\end{array}$ & ABU78036 & + & + & + & + & + & + & + \\
\hline & $\begin{array}{l}\text { Transcription repressor of multidrug efflux pump acrAB TetR (AcrR) } \\
\text { family }\end{array}$ & ABU78864 & + & + & + & + & + & + & + \\
\hline Plasmic & Periplasmic component of efflux system & ABU76384 & + & - & - & - & - & - & - \\
\hline E.P & Outer membrane efflux family protein & ABU76385 & + & - & - & - & - & - & - \\
\hline
\end{tabular}


Table 3. Prevalence and distribution and NCBI protein annotations of efflux pump associated genes among the seven Cronobacter species as described on the pan-genomic Cronobacter microarray ${ }^{\text {a }}$.

\begin{tabular}{|c|c|c|c|c|c|c|c|c|c|}
\hline Family & Sub-Cluster & $\begin{array}{c}\text { NCBI } \\
\text { Efflux Protein }\end{array}$ & C. sak & C.tur & C. $d u b$ & C.con & C. mal & C. muy & C. uni \\
\hline \multirow{2}{*}{ CorC } & Magnesium and cobalt efflux protein CorC & ABU76695 & + & + & + & + & + & + & + \\
\hline & Magnesium and cobalt efflux protein CorC & ABU77911 & + & + & + & + & + & + & + \\
\hline Mac & Macrolide-specific efflux protein MacA & ABU77706 & + & + & + & + & + & + & + \\
\hline DMT & Putative DMT superfamily metabolite efflux protein precursor & ABU77772 & + & + & + & + & + & + & + \\
\hline MFP & Predicted membrane fusion protein (MFP) component of efflux & ABU77795 & + & + & + & + & + & - & + \\
\hline Lactone & Homoserine/homoserine lactone efflux protein & ABU78933 & + & + & + & + & + & + & + \\
\hline MATE & $\begin{array}{l}\text { Multi antimicrobial extrusion protein }(\mathrm{Na}(+) \text { driven), MATE family of } \\
\text { MDR efflux pumps }\end{array}$ & ABU77280 & + & + & + & + & + & + & + \\
\hline \multirow{7}{*}{ Transporter } & RND efflux system aminoglycoside inner membrane transporter & & & & & & & & \\
\hline & $\mathrm{CmeB}$ & ABU76058 & + & + & + & + & + & + & + \\
\hline & Sugar efflux transporter B & ABU76341 & + & + & + & + & + & + & + \\
\hline & Formate/nitrite efflux transporter (TC 2.A.44 family) & ABU77686 & + & + & + & + & + & + & + \\
\hline & ABC transporter multidrug efflux pump fused ATP-binding domains & ABU77796 & + & + & + & + & + & - & + \\
\hline & RND efflux system, inner membrane transporter $\mathrm{CmeB}$ & ABU78038 & + & + & + & + & + & + & + \\
\hline & $\begin{array}{l}\text { Cobalt/zinc/cadmium efflux RND transporter membrane fusion } \\
\text { protein, CzcB family }\end{array}$ & ABU79421 & + & + & - & - & + & - & - \\
\hline Unknown & Possible efflux pump & ABU78153 & - & + & + & + & + & + & + \\
\hline
\end{tabular}

${ }^{\mathrm{a}}$ Gene and NCBI annotation are adopted and described by Negrete et al. [143]. 


\section{Role of Plasmids}

Several plasmids of various sizes ranging from $4.4 \mathrm{kbp}$ to $197.3 \mathrm{kbp}$ have been described for Cronobacter species and a summary of these plasmids is shown in Table $3[33,47,52,53,144,145]$. pESA3-like plasmids (synonymous with plasmids pCTU1, pCS2, pCSK29544_1, and pSP291-1) are thought to be examples of a prototypic virulence plasmid that was originally described by Franco et al. [47]. Plasmid pEAS2 is similar to pCTU2, which are conjugative plasmids, and pCTU3 is a plasmid that contains gene clusters involved in heavy metal ( $\mathrm{Ag}, \mathrm{Cu}$, and Arsenic) efflux (efflux pumps such as RND EPs); and maintenance of these plasmids seem to be under tight control by multiple toxin-antitoxin genes of both type I and type II classes of toxin-antitoxin (TA) genes [46,52,53,102,145]. TA genes are thought to help stabilize plasmids and mobile genetic elements or genetic cassettes, and they participate in the response to stressful growth conditions. Activation of TAs in response to stress is thought to control the metabolic load of cells within a population by eliminating part of the population (through outer membrane lysis); this is followed by the surviving cells entering a physiological resting or dormant state [146]. Interestingly, a type II toxin-antitoxin system HipA family toxin gene (WP_041460783) is located just downstream of the iucABCD/iutA Cronobactin siderophore and the TonB-dependent siderophore receptor genes (WP_041460784.1) [46,47]. There are also chromosomally located TAs which have been shown to control several bacterial processes, like biofilm formation, survival during infection of eukaryotic cells, defense against invading bacteriophages and entrance and exit into persistence [146].

The role of pESA3/pCTU1 plasmids in virulence was confirmed by Eshwar et al. [76], who showed that strains harboring plasmids pESA3 and pCTU1 exhibited twice the mortality rate than isogenically plasmid-cured strains or naturally occurring plasmid-free strains using the Zebrafish infection model. These data suggest that these plasmids are virulence-associated but may not represent the entire virulence factor gene repertoire of Cronobacter. pESA3/pCTU1-like plasmids encode a single RepFIB-like origin of replication gene, repA, as well as genes for two iron acquisition systems (eitCBAD and iucABCD/iutA). pESA3-like plasmids possessed by C. sakazakii also harbor a type VI secretion system that controls the secretion of toxic proteins such as Hcp1 and VrgR [47]. Tables 1, 4 and 5 describe the various loci carried on these plasmids in greater detail as harbored by the various Cronobacter species. Tables 1 and 5 show the prevalence and distribution of the pESA3/pCTU1-like virulence plasmids compared to pESA2/pCTU2-like conjugal and pCTU3-like plasmids among 570 Cronobacter strains. Table 4 describes the genomic characteristics of completely sequenced plasmids carried by the seven Cronobacter species. 
Table 4. Characteristics of known plasmids possessed by Cronobacter species ${ }^{\mathrm{a}, \mathrm{b}}$.

\begin{tabular}{|c|c|c|c|c|c|c|c|c|c|}
\hline Cronobacter Species and Strain & Plasmid Name & RefSeq & INSDC & Size $(\mathrm{Kb})$ & GC (\%) & Protein & Gene & Pseudogene & Reference \\
\hline C. universalis NCTC 9529 & pCUNV1 & NZ_CP012258.1 & СР012258 & 129.8 & 57.0 & 118 & 119 & 1 & 46 \\
\hline C. sakazakii 29544 & CSK29544_1p & NZ_CP011048.1 & СР011048 & 93.9 & 57.0 & 61 & 69 & 8 & unpublished \\
\hline C. sakazakii 29544 & CSK29544_2p & NZ_CP011049.1 & СР011049 & 4.9 & 54.9 & 4 & 7 & 3 & unpublished \\
\hline C. sakazakii 29544 & CSK29544_3p & NZ_CP011050.1 & СР011050 & 53.5 & 50.1 & 58 & 61 & 3 & unpublished \\
\hline C. sakazakii 29544 & pCSA2 & NC_021293.1 & KC663407 & 5.1 & 55.0 & 6 & 6 & 0 & unpublished \\
\hline C. sakazakii NCIMB 8272, NCTC 8155 & pCS1 & NZ CP012254.1 & СР012254 & 110.1 & 50.7 & 125 & 133 & 7 & 46 \\
\hline C. sakazakii NCIMB 8272, NCTC 8155 & pCS2 & NZ_CP012255.1 & СР012255 & 117.8 & 57.2 & 103 & 107 & 4 & 46 \\
\hline C. sakazakii NCIMB 8272, NCTC 8155 & pCS3 & NZ_CP012256.1 & СР012256 & 53.4 & 49.3 & 55 & 59 & 4 & 46 \\
\hline C. sakazakii ATCC BAA-894 & pESA2 & NC 009779.1 & СР000784 & 31.2 & 51.6 & 36 & 38 & 2 & 28 \\
\hline C. sakazakii ATCC BAA-894 & pESA3 & NC_009780.1 & СР000785 & 131.2 & 56.9 & 118 & 120 & 2 & 28 \\
\hline C. sakazakii SP291 & pSP291-2 & NC_020261.1 & СР004093 & 52.1 & 49.2 & 47 & 58 & 11 & 130 \\
\hline C. sakazakii SP291 & pSP291-3 & NC_020262.1 & СР004094 & 4.4 & 54.0 & 4 & 6 & 2 & 130 \\
\hline C. sakazakii SP291 & pSP291-1 & NC_020263.1 & СР004092 & 118.1 & 57.2 & 101 & 108 & 7 & 130 \\
\hline C. turicensis z 3032 & pCTU1 & NC_013283.1 & FN543094 & 138.3 & 56.1 & 109 & 119 & 10 & 45 \\
\hline C. turicensis z 3032 & pCTU2 & NC_013284.1 & FN543095 & 22.5 & 49.2 & 27 & 28 & 1 & 45 \\
\hline C. turicensis z3032 & pCTU3 & NC_013285.1 & FN543096 & 53.8 & 50.0 & 55 & 62 & 7 & 45 \\
\hline C. dublinensis LMG 23823 & pCDU1 & NZ_CP012267.1 & СР012267 & 197.3 & 56.8 & 159 & 163 & 4 & 46 \\
\hline C. condimenti 1330 & pCCO1 & NZ_CP012265.1 & СР012265 & 151.5 & 54.0 & 126 & 138 & 12 & 46 \\
\hline C. malonaticus CMCC 45402 & p1 & NC_023024.1 & СР006732 & 126.5 & 57.3 & 102 & 104 & 2 & 131 \\
\hline C. malonaticus CMCC 45402 & p2 & NC_023025.1 & СР006733 & 55.9 & 50.4 & 63 & 64 & 1 & 131 \\
\hline C. malonaticus LMG 23826 & pCMA1 & NZ_CP013941.1 & СР013941 & 126.5 & 57.3 & 104 & 105 & 1 & 46 \\
\hline C. malonaticus LMG 23826 & pCMA2 & NZ_CP013942.1 & СР013942 & 52.6 & 50.3 & 58 & 61 & 3 & 46 \\
\hline
\end{tabular}

${ }^{a}$ Information was obtained from NCBI and then summarized. ${ }^{b}$ The authors would like to remind the readers that many of the plasmids and their genetic loci described in this section possess great nucleotide sequence homology among the different plasmids types (e.g., the virulence plasmids), but the prevalence and distribution of the genetic loci are based on PCR detection using pESA3-pCTU1 sequence inferences. 
Table 5. Prevalence and distribution of virulence factors harbored on the pESA3/pCTU1/pSP291-like incFIB virulence plasmid observed in 570 Cronobacter isolates.

\begin{tabular}{|c|c|c|c|c|c|c|c|c|c|c|}
\hline \multirow{3}{*}{ Species } & \multirow{3}{*}{$\begin{array}{l}\text { No. of } \\
\text { Isolates }\end{array}$} & \multirow{3}{*}{$\begin{array}{c}\text { pESA3/ } \\
\text { pCTU1 }^{\text {(incFIB) }}{ }^{b}\end{array}$} & \multicolumn{8}{|c|}{ No. of Isolates with the Indicated Plasmidotype (\%) a } \\
\hline & & & \multicolumn{5}{|c|}{ T6SS } & FHA & \multicolumn{2}{|c|}{ Iron Acquisition } \\
\hline & & & cpa & Int $L$ & $\operatorname{vgrG}$ & $R$ end & Int $R$ & fhaB & eitA & iucC \\
\hline C. sakazakii & 507 & $493(97)$ & $479(97)$ & $484(98)$ & $273(55)$ & $297(60)$ & $183(37)$ & 59 (12) & $489(99)$ & 487 (99) \\
\hline C. malonaticus & 30 & $30(100)$ & $0(0)$ & $3(10)$ & $1(3)$ & $0(0)$ & $0(0)$ & $30(100)$ & $30(100)$ & $29(97)$ \\
\hline C. turicensis & 13 & $13(100)$ & $0(0)$ & $1(8)$ & $2(15)$ & $0(0)$ & $0(0)$ & $13(100)$ & $13(100)$ & $13(100)$ \\
\hline C. muytjensii & 12 & $9(75)$ & $0(0)$ & $0(0)$ & $0(0)$ & $0(0)$ & $0(0)$ & $0(0)$ & $9(100)$ & $1(11)$ \\
\hline C. dublinensis & 5 & $4(80)$ & $0(0)$ & $0(0)$ & $0(0)$ & $0(0)$ & $0(0)$ & $0(0)$ & $4(100)$ & $1(25)$ \\
\hline C. universalis & 2 & $2(100)$ & $2(100)$ & $0(0)$ & $0(0)$ & $0(0)$ & $0(0)$ & $2(100)$ & $2(100)$ & $2(100)$ \\
\hline C. condimenti & 1 & $1(100)$ & $0(0)$ & $0(0)$ & $0(0)$ & $0(0)$ & $0(0)$ & $0(0)$ & $1(100)$ & $1(100)$ \\
\hline Total & 570 & $552(97)$ & $481(87)$ & $487(88)$ & $276(50)$ & $297(54)$ & $183(33)$ & $104(19)$ & $548(99)$ & $534(97)$ \\
\hline
\end{tabular}

a The information on strains summarized in this table come from studies reported by Franco et al. [47], Gopinath et al. [68], Jang et al. [129,130], and Tall et al. [147]. Numbers within parentheses are the percentage PCR-positive for each plasmid gene locus in relation to the total number of plasmid (incFIB)-harboring strains of each of the seven Cronobacter species as described by Franco et al. [47]. ${ }^{b}$ The prevalence percentage of pESA3/pCTU1 (incFIB) plasmid among the Cronobacter strains was calculated using the total number of strains tested. 


\section{Role of Secreted and Assembled Cell Surface Proteins (Adherence Factors) in Disease and Persistence}

It is generally considered that the ability of pathogenic bacteria to adhere to an epithelial cell surface is the first step in pathogenesis [148]. Bacteria express filamentous assemblies of protein subunits called pili or fimbriae which are used to colonize a host cell membrane surface or as conduits for the secretion of substrates (e.g., T4SS fimbriae). These adherence factors are proteinaceous assemblies that extend from the cell surface and are secreted and assembled by either a chaperone/usher-dependent or a structural subunit/nucleator-precipitation pathway [149]. Fimbriae facilitate adherence of bacterial cells to host tissue cells through the interaction with host receptors located on surface of the target cell. These interactions are often tissue specific, which occur either with the fimbriae main structural subunit or with associated fimbrial adhesins and arise through recognition by the fimbrial adhesin of certain chemical groups of host ligands (various glycosylated membrane receptors) [149]. The genetic loci coding for these structures are found both on the chromosome and on plasmids [149].

Grim et al. [102] described eight fimbriae types in the seven Cronobacter species that were based on the chaperone-usher classification system described by Humphries et al. [150]. These included fimbriae identified as $\gamma 1, \gamma 4, \kappa, \beta, \pi$, and $\Sigma$ types, curli, and a P-pilus homologue, that were differentially dispersed among the Cronobacter genomes analyzed in their study [102]. Some genomes also harbored curli biosynthesis genes, which are homologous to curli of E. coli and thin-aggregative fimbriae of Salmonella $[149,150]$. Curli fimbriae belong to a type of highly aggregated surface protein fibers (6-8 nm in diameter and $1 \mu \mathrm{m}$ in length) that are related to proteins called amyloids and are involved in adhesion to other cells or material surfaces. They have also been found to be involved in cell-cell aggregation, and biofilm development [150]. The biosynthesis of curli is encoded by two operons, $\operatorname{csgBAC}$ and $\operatorname{csg} D E F G$ (csg, curli-specific genes in E. coli) [150]. The major curlin structural subunit encoded by $\operatorname{csg} A$ and $\operatorname{csg} B$ encodes a nucleator protein subunit while $\operatorname{csg} C$ may have accessory function in the formation of curli fimbriae [141]. Curli fimbriae are not assembled if CsgB is absent, so CsgA is secreted from the cell as an unpolymerized exoprotein [150]. Using primers designed to detect the structural curlin subunit gene $(\operatorname{csg} A)$ and a putative assembly factor gene $(\operatorname{csg} G), \mathrm{Hu}$ [151] found that $\operatorname{csg} A$ was found in C. dublinensis, C. malonaticus, C. turicensis and C. universalis, but not in C. sakazakii and C. muytjensii. Using the PATRIC tool and NCBI's genome protein tables, Jang et al. [88] showed that the prevalence and distribution of Type 1, Beta, Sigma, Pap, and Curli fimbriae gene clusters possessed by the seven Cronobacter species followed species lines and are summarized in Table 6. For example, Beta fimbriae were only seen in C. sakazakii strains and Curli fimbriae were not found in C. sakazakii nor C. muytjensii strains. Interestingly, C. muytjensii strains also did not possess genes for Sigma fimbriae (Table 6). 
Table 6. Prevalence and distribution of type 1, Beta, Sigma, Pap, and Curli fimbriae gene clusters possessed by the seven Cronobacter species ${ }^{\text {a }}$.

\begin{tabular}{|c|c|c|c|c|c|c|c|}
\hline \multicolumn{8}{|c|}{ Cronobacter Species and Species-Associated Fimbriae Types Analyzed Using the PATRIC Database (Number of Strains) [152] } \\
\hline Fimbriae type & $\begin{array}{c}\text { C. sakazakii } \\
(145)\end{array}$ & $\begin{array}{c}\text { C. malonaticus } \\
\text { (2) }\end{array}$ & $\begin{array}{l}\text { C. turicensis } \\
\text { (2) }\end{array}$ & $\begin{array}{c}\text { C. muytjensii } \\
\text { (3) }\end{array}$ & $\begin{array}{c}\text { C. dublinensis } \\
\text { (2) }\end{array}$ & $\begin{array}{l}\text { C. universalis } \\
\text { (1) }\end{array}$ & $\begin{array}{l}\text { C. condimenti } \\
\text { (1) }\end{array}$ \\
\hline Beta ${ }^{b}$ & 136 & 0 & 0 & 0 & 0 & 0 & 0 \\
\hline Sigma $^{c}$ & 137 & 2 & 1 & 0 & 2 & 1 & 1 \\
\hline Type1 $\mathrm{d}$ & 137 & 2 & 2 & 3 & 2 & 1 & 1 \\
\hline Pap ${ }^{e}$ & 137 & 2 & 2 & 3 & 2 & 1 & 1 \\
\hline Curli ${ }^{f}$ & 0 & 2 & 1 & 0 & 2 & 1 & 1 \\
\hline
\end{tabular}

${ }^{a}$ This table was adapted from Jang et al. [88]. ${ }^{b}$ The number of strains for Beta fimbriae reflects the presence of Beta-fimbriae probable major subunit. ${ }^{c}$ The number of strains with Sigma fimbriae reflects the presence of Sigma-fimbriae chaperone protein, Sigma-fimbriae tip adhesin, Sigma-fimbriae uncharacterized paralogous subunit, and Sigma-fimbriae usher protein. ${ }^{d}$

The number of strains with Type1 fimbriae reflects the presence of Type 1 fimbriae anchoring protein FimD and Type 1 fimbriae adaptor subunit FimG. e The number of strains with Pap fimbriae reflects the presence of PapA, P pilus assembly protein (COG3121), and chaperone PapD. ${ }^{\mathrm{f}}$ The number of strains with Curli fimbriae reflect the presence of CsgA or CsgB. 


\section{Iron Transport}

Iron is used as a cofactor in many essential enzymes involved in basic cellular functions, which are also associated with metabolic pathways of both pathogens and their hosts $[153,154]$. Iron is found in two forms, Ferric $\left(\mathrm{Fe}^{+3}\right)$ and Ferrous $\left(\mathrm{Fe}^{+2}\right)$ iron. Within the host, $\mathrm{Fe}^{+3}$ iron is usually only available when it is bound to specific proteins, such as transferrin, lactoferrin, and ferritin, or when it is complexed with hemoproteins $[153,154]$. The Ferric $\left(\mathrm{Fe}^{+3}\right)$ storage form must be reduced to $\left(\mathrm{Fe}^{+2}\right)$ to cross a plasma membrane. During evolution and associations with their various ancestral hosts, bacteria have developed several mechanisms to utilize indigenous stores of host iron. Specialized iron-uptake systems have been found in most bacterial species, and these systems allow microorganisms to compete for iron within hosts or as members of mixed microbial environmental communities. As mentioned earlier, Franco et al. found that pESA3/pCTU1-like plasmids encode common virulence factors, including a hydroxamate-type or aerobactin-like siderophore named cronobactin (iucABCD and the receptor gene iut $A$ ) and an $A B C$ ferric-iron transporter gene cluster eit $A B C D$ [47]. In Gram-negative bacteria, siderophores are specialized iron binding ligands, which sequester the iron and subsequently interact with siderophore receptors and an ATP-driven porin-like (TonB- like) transporter protein located in the bacterial outer membrane.

In addition to the plasmid-borne iron acquisition gene clusters, Cronobacter spp. have other transport systems to transport both ferric and ferrous iron. These systems include genes encoding ferric and ferrous transporters and heme-iron extractors, as well as putative TonB-dependent iron receptors and ferric reductases [102]. For acquisition of ferrous iron, all Cronobacter species have two ferrous iron transporters systems (Feo and Efe), and for transport of ferric iron, all plasmid-harboring strains $(97 \%)$ have the siderophore cronobactin [102]. Cronobacter species also harbor genes homologous to the fhu $A C D B$ operon of $E$. coli which suggests that, like E. coli, Cronobacter species can scavenge iron from siderophores produced and secreted by other microorganisms [102]. Interestingly, phylogenetic analysis of most of the iron acquisition genes and systems separate the genus Cronobacter into two subclades: one subclade includes the species C. sakazakii, C. malonaticus, C. universalis, and C. turicensis, and the other subclade is comprised of $C$. muytjensii and $C$. dublinensis which is similar to that described by Grim et al. [102] for members of the genus. For a comprehensive review on the synthesis and characteristics of the various iron transport systems and associated proteins that Cronobacter species possess, please refer to a paper by Grim et al. [102].

\section{Conclusions}

Cronobacter species and the diseases they cause have undergone a significant adjustment since 2008 when Iversen et al. [1] and Joseph et al. [2] reclassified the genus into its current seven species; and undoubtedly this taxonomic scheme will continue to evolve. Once thought to be only a harmless inhabitant of the intestinal tract of humans, Cronobacter species are now considered to be a group of pathogens with notable versatility in their ability to cause human disease in all age groups. However, neonates and infants are still regarded as the age groups that are highly susceptible to invasive disease and disease susceptibility can now be extended to adults, primarily elderly individuals. Various species-specific virulence factors have been described that can adversely affect a wide range of eukaryotic cell processes including protein synthesis, cell division, and ion secretion. Many of these factors are toxins that have been shown to also modulate the host immune system. These factors are also encoded on a variety of mobile genetic elements such as plasmids and transposons; this genomic plasticity implies ongoing re-assortment of virulence factor genes and will undoubtedly continue to complicate our efforts to categorize Cronobacter into sharply defined genomic pathotypes. Furthermore, much information regarding its association with the postpartum intestinal microbiota is also warranted so to determine if a human carriage state is involved in the transmission of Cronobacter from infant caretakers to susceptible infants. Lastly, more in-depth surveillance studies using species-specific identification methodologies that at least include results of species-specific PCR assays, or at best, species identities obtained from next generation sequencing (NGS) studies are 
needed to obtain a clearer epidemiologic picture as to which Cronobacter species are responsible for infections. Accordingly, the collective suggestion of public health and food safety officials is to elevate Cronobacter species to the level where it should be mandatorily submitted to the various centralized disease reporting systems as suggested by Tall et al. [147]. Two such systems are the National Notifiable Diseases Surveillance System, which is maintained by the Centers for Disease Control and Prevention (Available online: https://wwwn.cdc.gov/nndss/data-and-statistics.html, last accessed 1/17/2020) and the European Centre for Disease Prevention and Control's Surveillance System (Available online: TESSy, https://ecdc.europa.eu/en/publications-data/european-surveillance-system-tessy, last accessed 1/17/2020) [20,155]. Currently, Minnesota is the only state in the USA that does this. In summary, many of these bacterial factors described in this review are toxins or exoproteins which have been shown to also modulate the host immune response. Many of the genes for these proteins are encoded on a variety of mobile genetic elements such as plasmids; this genomic plasticity seems to be common among the seven species and also indicates ongoing re-assortment of future virulence factor genes. Such genomic reassortments have complicated efforts to categorize Cronobacter into sharply defined genomic pathotypes. As the use of WGS increases, it is hoped that the finding of new genomic attributes will allow for a better understanding of virulence. Combining this information with an improved epidemiological reporting system will lead to a more comprehensive understanding of toxin secretion and virulence. The ultimate goal would be improved patient care enabling better clinical outcomes.

Author Contributions: Conception of the work: H.J., B.D.T., S.F., R.S., G.R.G., and A.L.; Data acquisition: H.J., S.B.F., A.E., F.N., J.G., I.R.P., J.W., S.S., S.N., and Y.L.; Interpretations: H.J., G.R.G., A.E., S.S., S.N., J.G., I.R.P., S.B.F., F.N., J.W., Y.L., S.F., B.D.T., R.S., and A.L.; Writing and revising: H.J., G.R.G., A.E., S.S., S.N., J.G., I.R.P., S.B.F., F.N., J.W., Y.L., S.F., B.D.T., R.S., and A.L. All authors have read and agreed to the published version of the manuscript.

Funding: This research was internally funded through U.S. FDA appropriations, and in part by the University of Maryland JIFSAN Program through a cooperative agreement with the FDA (no. FDU001418).

Acknowledgments: We thank the student internship programs sponsored by the Office of International Affairs of Gachon University, Gyeonggi, Republic of Korea for supporting student interns, JungHa Woo and YouYoung Lee. We thank the University of Maryland, Joint Institute for Food Safety and Applied Nutrition (JIFSAN) for supporting JIFSAN interns, Samantha Finkelstein and Flavia Negrete. We also thank the Oak Ridge Institute for Science and Education, Oak Ridge, Tennessee for sponsoring research fellow Hyein Jang.

Conflicts of Interest: The authors declare no conflict of interest.

\section{References}

1. Iversen, C.; Mullane, N.; Mccardell, B.; Tall, B.D.; Lehner, A.; Fanning, S.; Stephan, R.; Joosten, H. Cronobacter gen. nov., a new genus to accommodate the biogroups of Enterobacter sakazakii, and proposal of Cronobacter sakazakii gen. nov., comb. nov., Cronobacter malonaticus sp. nov., Cronobacter turicensis sp. nov., Cronobacter muytjensii sp. nov., Cronobacter dublinensis sp. nov., Cronobacter genomospecies 1, and of three subspecies, Cronobacter dublinensis subsp. dublinensis subsp. nov., Cronobacter dublinensis subsp. lausannensis subsp. nov. and Cronobacter dublinensis subsp. lactaridi subsp. nov. Int. J. Syst. Evol. Microbiol. 2008, 58, 1442-1447. [PubMed]

2. Joseph, S.; Cetinkaya, E.; Drahovska, H.; Levican, A.; Figueras, M.J.; Forsythe, S.J. Cronobacter condimenti sp. nov., isolated from spiced meat, and Cronobacter universalis sp. nov., a species designation for Cronobacter sp. genomospecies 1, recovered from a leg infection, water and food ingredients. Int. J. Syst. Evol. Microbiol. 2012, 62, 1277-1283. [CrossRef] [PubMed]

3. Stephan, R.; Grim, C.J.; Gopinath, G.R.; Mammel, M.K.; Sathyamoorthy, V.; Trach, L.H.; Chase, H.R.; Fanning, S.; Tall, B.D. Re-examination of the taxonomic status of Enterobacter helveticus, Enterobacter pulveris and Enterobacter turicensis as members of the genus Cronobacter and their reclassification in the genera Franconibacter gen. nov. and Siccibacter gen. nov. as Franconibacter helveticus comb. nov., Franconibacter pulveris comb. nov. and Siccibacter turicensis comb. nov., respectively. Int. J. Syst. Evol. Microbiol. 2014, 64, 3402-3410. [PubMed]

4. Iversen, C.; Forsythe, S. Risk profile of Enterobacter sakazakii, an emerging pathogen associated with infant milk formula. Trends Food Sci. Technol. 2003, 14, 443-454. [CrossRef] 
5. FAO/WHO. Enterobacter sakazakii and other Microorganisms in Powdered Infant Formula: Meeting Report; Microbiological Risk Assessment Series, No. 6; FAO/WHO: Rome, Italy, 2004; Available online: http: //www.fao.org/3/a-y5502e.pdf (accessed on 17 January 2020).

6. FAO/WHO (Food and Agriculture Organization of the United Nations/World Health Organization). Enterobacter sakazakii (Cronobacter spp.) in Powdered Follow-up Formulae; Microbiol Risk Assess Series No. 15; FAO/WHO: Rome, Italy, 2008; Available online: https://www.who.int/foodsafety/publications/micro/ MRA_followup.pdf (accessed on 17 January 2020).

7. Lai, K.K. Enterobacter sakazakii infections among neonates, infants, children, and adults. Case reports and a review of the literature. Medicine 2001, 80, 113-122. [CrossRef] [PubMed]

8. Bowen, A.B.; Braden, C.R. Invasive Enterobacter sakazakii disease in infants. Emerg. Infect. Dis. 2006, 12, 1185-1189. [CrossRef] [PubMed]

9. Masood, N.; Moore, K.; Farbos, A.; Paszkiewicz, K.; Dickins, B.; McNally, A.; Forsythe, S. Genomic dissection of the 1994 Cronobacter sakazakii outbreak in a French neonatal intensive care unit. BMC Genom. 2015, 16, 750. [CrossRef]

10. Gosney, M.A.; Martin, M.V.; Wright, A.E.; Gallagher, M. Enterobacter sakazakii in the mouths of stroke patients and its association with aspiration pneumonia. Eur. J. Intern. Med. 2006, 17, 185-188. [CrossRef]

11. Jason, J. Prevention of invasive Cronobacter infections in young infants fed powdered infant formulas. Pediatrics 2012, 130, e1076-e1084. [CrossRef]

12. Holy, O.; Forsythe, S. Cronobacter spp. as emerging causes of healthcare-associated infection. J. Hosp. Infect. 2014, 86, 169-177. [CrossRef]

13. Patrick, M.E.; Mahon, B.E.; Greene, S.A.; Rounds, J.; Cronquist, A.; Wymore, K.; Boothe, E.; Lathrop, S.; Palmer, A.; Bowen, A. Incidence of Cronobacter spp. infections, United States, 2003-2009. Emerg. Infect. Dis. 2014, 20, 1520-1523. [CrossRef] [PubMed]

14. Holy, O.; Petrzelova, J.; Hanulik, V.; Chromá, M.; Matoušková, I.; Forsythe, S.J. Epidemiology of Cronobacter spp. isolates from patients admitted to the Olomouc University Hospital (Czech Republic). Epidemiol. Mikrobiol. Imunol. 2014, 63, 69-72. [PubMed]

15. Alsonosi, A.; Hariri, S.; Kajsik, M.; Oriešková, M.; Hanulík, V.; Röderová, M.; Petrželová, J.; Kollárová, H.; Drahovská, H.; Forsythe, S. The speciation and genotyping of Cronobacter isolates from hospitalised patients. Eur. J. Clin. Microbiol. Infect. Dis. 2015, 34, 1979-1988. [CrossRef] [PubMed]

16. Urmenyi, A.M.; Franklin, A.W. Neonatal death from pigmented coliform infection. Lancet 1961, 1, $313-315$. [CrossRef]

17. Himelright, I.; Harris, E.; Lorch, V.; Anderson, M.; Jones, T.; Craig, A.; Kuehnert, M.; Forster, T.; Arduino, M.; Jensen, B.; et al. Enterobacter sakazakii infections associated with the use of powdered infant formula-Tennessee, 2001. Morb. Mortal. Wkly. Rep. 2002, 51, 297-300.

18. Henry, M.; Fouladkhah, A. Outbreak history, biofilm formation, and preventive measures for control of Cronobacter sakazakii in infant formula and infant care settings. Microorganisms 2019, 7, 77. [CrossRef]

19. Noriega, F.R.; Kotloff, K.L.; Martin, M.A.; Schwalbe, R.S. Nosocomial bacteremia caused by Enterobacter sakazakiki and Leuconostoc mesenteroides resulting from extrinsic contamination of infant formula. Pediatr. Infect. Dis. J. 1990, 9, 447-449.

20. Friedemann, M. Enterobacter sakazakii in food and beverages (other than infant formula and milk powder). Int. J. Food. Microbiol. 2007, 116, 1-10. [CrossRef]

21. Bowen, A.; Wiesenfeld, H.C.; Kloesz, J.L.; Pasculle, A.W.; Nowalk, A.J.; Brink, L.; Elliot, E.; Martin, H.; Tarr, C.L. Notes from the Field: Cronobacter sakazakii infection associated with feeding extrinsically contaminated expressed human milk to a premature infant-Pennsylvania. Morb. Mortal. Wkly. Rep. 2017, 66, 761-762. [CrossRef]

22. McMullan, R.; Menon, V.; Beukers, A.G.; Jensen, S.O.; van Hal, S.J.; Davis, R. Cronobacter sakazakii infection from expressed breast milk, Australia. Emerg. Infect. Dis. 2018, 24, 393-394. [CrossRef]

23. Osaili, T.M.; Shaker, R.R.; Al-Haddaq, M.S.; Al-Nabulsi, A.A.; Holley, R.A. Heat resistance of Cronobacter species (Enterobacter sakazakii) in milk and special feeding formula. J. Appl. Microbiol. 2009, 107, 928-935. [CrossRef] [PubMed]

24. Pava-Ripoll, M.; Pearson, R.E.; Miller, A.K.; Ziobro, G.C. Prevalence and relative risk of Cronobacter spp., Salmonella spp., and Listeria monocytogenes associated with the body surfaces and guts of individual filth flies. Appl. Environ. Microbiol. 2012, 78, 7891-7902. [CrossRef] [PubMed] 
25. Sani, N.A.; Odeyemi, O.A. Occurrence and prevalence of Cronobacter spp. in plant and animal derived food sources, a systematic review and meta-analysis. Springerplus 2015, 4, 545. [CrossRef] [PubMed]

26. Muller, A.; Stephan, R.; Fricker-Feer, C.; Lehner, A. Genetic diversity of Cronobacter sakazakii isolates collected from a Swiss infant formula production facility. J. Food Prot. 2013, 76, 883-887. [CrossRef]

27. Yan, Q.; Wang, J.; Gangiredla, J.; Cao, Y.; Martins, M.; Gopinath, G.R.; Stephan, R.; Lampel, K.; Tall, B.D.; Fanning, S. Comparative genotypic and phenotypic analysis of Cronobacter species cultured from four powdered infant formula production facilities: Indication of pathoadaptation along the food chain. Appl. Environ. Microbiol. 2015, 81, 4388-4402. [CrossRef]

28. Berthold-Pluta, A.; Garbowska, M.; Stefanska, I.; Pluta, A. Microbiological quality of selected ready-to-eat leaf vegetables, sprouts and non-pasteurized fresh fruit-vegetable juices including the presence of Cronobacter spp. Food Microbiol. 2017, 65, 221-230. [CrossRef]

29. Vasconcellos, L.; Carvalho, C.T.; Tavares, R.O.; de Mello Medeiros, V.; de Oliveira Rosas, C.; Silva, J.N.; Dos Reis Lopes, S.M.; Forsythe, S.J.; Brandão, M.L.L. Isolation, molecular and phenotypic characterization of Cronobacter spp. in ready-to-eat salads and foods from Japanese cuisine commercialized in Brazil. Food Res. Int. 2018, 107, 353-359. [CrossRef]

30. Lehner, A.; Tall, B.D.; Fanning, S. Cronobacter spp.-Opportunistic foodborne pathogens: An Update on evolution, osmotic adaptation and pathogenesis. Curr. Clin. Microbiol. Rep. 2018, 5, 97-105. [CrossRef]

31. Cruz-Córdova, A.; Rocha-Ramírez, L.M.; Ochoa, S.A.; González-Pedrajo, B.; Espinosa, N.; Eslava, C.; Hernández-Chiñas, U.; Mendoza-Hernández, G.; Rodríguez-Leviz, A.; Valencia-Mayoral, P.; et al. Flagella from five Cronobacter species induce pro-inflammatory cytokines in macrophage derivatives from human monocytes. PLoS ONE 2012, 7, e52091. [CrossRef]

32. Jaradat, Z.W.; Al Mousa, W.; Elbetieha, A.; Al Nabulsi, A.; Tall, B.D. Cronobacter spp.-Opportunistic food-borne pathogens. A review of their virulence and environmental-adaptive traits. J. Med. Microbiol. 2014, 63, 1023-1037. [CrossRef]

33. Kucerova, E.; Clifton, S.W.; Xia, X.Q.; Long, F.; Porwollik, S.; Fulton, L.; Fronick, C.; Minx, P.; Kyung, K.; Warren, W.; et al. Genome sequence of Cronobacter sakazakii BAA-894 and comparative genomic hybridization analysis with other Cronobacter species. PLoS ONE 2010, 5, e9556. [CrossRef] [PubMed]

34. Iversen, C.; Lane, M.; Forsythe, S.J. The growth profile, thermotolerance and biofilm formation of Enterobacter sakazakii grown in infant formula milk. Lett. Appl. Microbiol. 2004, 38, 378-382. [CrossRef] [PubMed]

35. Lehner, A.; Riedel, K.; Eberl, L.; Breeuwer, P.; Diep, B.; Stephan, R. Biofilm formation, extracellular polysaccharide production, and cell-to-cell signaling in various Enterobacter sakazakii strains: Aspects promoting environmental persistence. J. Food Prot. 2005, 68, 2287-2294. [CrossRef] [PubMed]

36. Kim, H.; Ryu, J.H.; Beuchat, L.R. Attachment of and biofilm formation by Enterobacter sakazakii on stainless steel and enteral feeding tubes. Appl. Environ. Microbiol. 2006, 72, 5846-5856. [CrossRef] [PubMed]

37. Grimm, M.; Stephan, R.; Iversen, C.; Manzardo, G.G.; Rattei, T.; Riedel, K.; Ruepp, A.; Frishman, D.; Lehner, A. Cellulose as an extracellular matrix component present in Enterobacter sakazakii biofilms. J. Food Prot. 2008, 71, 13-18. [CrossRef]

38. Hoeflinger, J.L.; Miller, M.J. Cronobacter sakazakii ATCC 29544 Autoaggregation requires FliC flagellation, not motility. Front. Microbiol. 2017, 8, 301. [CrossRef]

39. Suppiger, A.; Eshwar, A.K.; Stephan, R.; Kaever, V.; Eberl, L.; Lehner, A. The DSF type quorum sensing signalling system $\mathrm{RpfF} / \mathrm{R}$ regulates diverse phenotypes in the opportunistic pathogen Cronobacter. Sci. Rep. 2016, 6, 18753. [CrossRef]

40. Johnson, T.J.; Nolan, L.K. Pathogenomics of the virulence plasmids of Escherichia coli. Microbiol. Mol. Biol. Rev. 2009, 73, 750-774.

41. Smith, H.W.; Halls, S. Studies on Escherichia coli enterotoxin. J. Pathol. Bacteriol. 1967, 93, 531-543. [CrossRef]

42. Datta, N.; Hedges, R.W. Compatibility groups among fi-R factors. Nature 1971, 234, 222-223. [CrossRef]

43. Juhas, M.; Crook, D.W.; Hood, D.W. Type IV secretion systems: Tools of bacterial horizontal gene transfer and virulence. Cell. Microbiol. 2008, 10, 2377-2386. [CrossRef]

44. Mellata, M.; Touchman, J.W.; Curtiss, R. Full sequence and comparative analysis of the plasmid pAPEC-1 of avian pathogenic E. coli chi7122 (O78:K80:H9). PLoS ONE 2009, 4, e4232. [CrossRef] [PubMed]

45. Smith, H.W.; Linggood, M.A. Observations on the pathogenic properties of the K88, Hly and Ent plasmids of Escherichia coli with particular reference to porcine diarrhoea. J. Med. Microbiol. 1971, 4, 467-485. [CrossRef] [PubMed] 
46. Finkelstein, S.; Negrete, F.; Jang, H.; Gangiredla, J.; Mammel, M.; Patel, I.R.; Chase, H.R.; Woo, J.; Lee, Y.; Wang, C.Z.; et al. Prevalence, distribution, and phylogeny of type two toxin-antitoxin genes possessed by Cronobacter species where C. sakazakii homologs follow sequence type lineages. Microorganisms 2019, 7, 554 . [CrossRef] [PubMed]

47. Franco, A.A.; Hu, L.; Grim, C.J.; Gopinath, G.; Sathyamoorthy, V.; Jarvis, K.G.; Lee, C.; Sadowski, J.; Kim, J.; Kothary, M.H.; et al. Characterization of putative virulence genes on the related RepFIB plasmids harbored by Cronobacter spp. Appl. Environ. Microbiol. 2011, 77, 3255-3267. [CrossRef] [PubMed]

48. Muytjens, H.L.; Zanen, H.C.; Sonderkamp, H.J.; Kollée, L.A.; Wachsmuth, I.K.; Farmer, J.J., 3rd. Analysis of eight cases of neonatal meningitis and sepsis due to Enterobacter sakazakii. J. Clin. Microbiol. 1983, 18, 115-120. [CrossRef]

49. Biering, G.; Karlsson, S.; Clark, N.C.; Jónsdóttir, K.E.; Lúdvígsson, P.; Steingrímsson, O. Three cases of neonatal meningitis caused by Enterobacter sakazakii in powdered milk. J. Clin. Microbiol. 1989, 27, $2054-2056$. [CrossRef]

50. Simmons, B.P.; Gelfand, M.S.; Haas, M.; Metts, L.; Ferguson, J. Enterobacter sakazakii infections in neonates associated with intrinsic contamination of a powdered infant formula. Infect. Control Hosp. Epidemiol. 1989, 10, 398-401. [CrossRef]

51. Clark, N.C.; Hill, B.C.; O’hara, C.M.; Steingrimsson, O.; Cooksey, R.C. Epidemiologic typing of Enterobacter sakazakii in two neonatal nosocomial outbreaks. Diagn. Microbiol. Infect. Dis. 1990, 13, 467-472. [CrossRef]

52. Stephan, R.; Lehner, A.; Tischler, P.; Rattei, T. Complete genome sequence of Cronobacter turicensis LMG 23827, a food-borne pathogen causing deaths in neonates. J. Bacteriol. 2011, 193, 309-310. [CrossRef]

53. Moine, D.; Kassam, M.; Baert, L.; Tang, Y.; Barretto, C.; Ngom, B.; Klijn, A.; Descombes, P. Fully closed genome sequences of five type strains of the genus Cronobacter and one Cronobacter sakazakii strain. Genome Announc. 2016, 4, e00142-16. [CrossRef] [PubMed]

54. Grim, C.J.; Kothary, M.H.; Gopinath, G.; Jarvis, K.G.; Beaubrun, J.J.; McClelland, M.; Tall, B.D.; Franco, A.A. Identification and characterization of Cronobacter iron acquisition systems. Appl. Environ. Microbiol. 2012, 78, 6035-6050. [CrossRef] [PubMed]

55. Grant, J.R.; Stothard, P. The CGView Server, a comparative genomics tool for circular genomes. Nucleic Acids Res. 2008, 36, W181-W184. [CrossRef] [PubMed]

56. Jang, H.; Gopinath, G.R.; Negrete, F.; Weinstein, L.; Lehner, A.; Fanning, S.; Tall, B.D. Chapter 15. Cronobacter spp. In Foodborne Infections and Intoxications, 5th ed.; Morris, J.G., Ed.; Elsevier, Inc.: Cambridge, MA, USA, 2020.

57. Liu, H.; Cui, J.H.; Cui, Z.G.; Hu, G.C.; Yang, Y.L.; Li, J.; Shi, Y.W. Cronobacter carriage in neonate and adult intestinal tracts. Biomed. Environ. Sci. 2013, 26, 861-864. [PubMed]

58. Zogaj, X.; Bokranz, W.; Nimtz, M.; Römling, U. Production of cellulose and curli fimbriae by members of the family Enterobacteriaceae isolated from the human gastrointestinal tract. Infect. Immun. 2003, 71, 4151-4158. [CrossRef] [PubMed]

59. Farmer, J.J.; Asbury, M.A.; Hickman, F.W.; Brenner, D.J. Enterobacter sakazakii: A New Species of "Enterobacteriaceae" Isolated from Clinical Specimens. Int. J. Syst. Bacteriol. 1980, 30, 569-584. [CrossRef]

60. Baldwin, A.; Loughlin, M.; Caubilla-Barron, J.; Kucerova, E.; Manning, G.; Dowson, C.; Forsythe, S. Multilocus sequence typing of Cronobacter sakazakii and Cronobacter malonaticus reveals stable clonal structures with clinical significance which do not correlate with biotypes. BMC Microbiol. 2009, 9, 223. [CrossRef]

61. Joseph, S.; Sonbol, H.; Hariri, S.; Desai, P.; McClelland, M.; Forsythe, S.J. Diversity of the Cronobacter genus as revealed by multilocus sequence typing. J. Clin. Microbiol. 2012, 50, 3031-3039. [CrossRef]

62. Joseph, S.; Forsythe, S.J. Insights into the emergent bacterial pathogen Cronobacter spp., generated by multilocus sequence typing and analysis. Front. Microbiol. 2012, 3, 397. [CrossRef]

63. Joseph, S.; Forsythe, S.J. Predominance of Cronobacter sakazakii sequence type 4 in neonatal infections. Emerg. Infect. Dis. 2011, 17, 1713-1715. [CrossRef]

64. Hariri, S.; Joseph, S.; Forsythe, S.J. Cronobacter sakazakii ST4 strains and neonatal meningitis, United States. Emerg. Infect. Dis. 2013, 19, 175-177. [CrossRef] [PubMed]

65. Forsythe, S.J.; Dickins, B.; Jolley, K.A. Cronobacter, the emergent bacterial pathogen Enterobacter sakazakii comes of age; MLST and whole genome sequence analysis. BMC Genom. 2014, 15, 1121. [CrossRef] [PubMed]

66. Joseph, S.; Hariri, S.; Masood, N.; Forsythe, S. Sialic acid utilization by Cronobacter sakazakii. Microb. Inform. Exp. 2013, 3, 3. [CrossRef] 
67. Pightling, A.W.; Pagotto, F. Draft genome sequence of Cronobacter sakazakii clonal complex 45 Strain HPB5174, isolated from a powdered infant formula facility in Ireland. Genome Announc. 2014, 2, e00778-14. [CrossRef] [PubMed]

68. Gopinath, G.R.; Chase, H.R.; Gangiredla, J.; Eshwar, A.; Jang, H.; Patel, I.; Negrete, F.; Finkelstein, S.; Park, E.; Chung, T.; et al. Genomic characterization of malonate positive Cronobacter sakazakii serotype O:2, sequence type 64 strains, isolated from clinical, food, and environment samples. Gut. Pathog. 2018, 10, 11. [CrossRef] [PubMed]

69. Ogrodzki, P.; Forsythe, S. Capsular profiling of the Cronobacter genus and the association of specific Cronobacter sakazakii and C. malonaticus capsule types with neonatal meningitis and necrotizing enterocolitis. BMC Genom. 2015, 16, 758. [CrossRef]

70. Iversen, C.; Waddington, M.; Farmer, J.J., 3rd; Forsythe, S.J. The biochemical differentiation of Enterobacter sakazakii genotypes. BMC Microbiol. 2006, 6, 94. [CrossRef]

71. Franco, A.A.; Kothary, M.H.; Gopinath, G.; Jarvis, K.G.; Grim, C.J.; Hu, L.; Datta, A.R.; McCardell, B.A.; Tall, B.D. Cpa, the outer membrane protease of Cronobacter sakazakii, activates plasminogen and mediates resistance to serum bactericidal activity. Infect. Immun. 2011, 79, 1578-1587. [CrossRef]

72. Kukkonen, M.; Korhonen, T.K. The omptin family of enterobacterial surface proteases/adhesins, from housekeeping in Escherichia coli to systemic spread of Yersinia pestis. Int. J. Med. Microbiol. 2004, 294, 7-14. [CrossRef]

73. Hritonenko, V.; Stathopoulos, C. Omptin proteins, an expanding family of outer membrane proteases in Gram-negative Enterobacteriaceae. Mol. Membr. Biol. 2007, 24, 395-406. [CrossRef]

74. Haiko, J.; Suomalainen, M.; Ojala, T.; Lähteenmäki, K.; Korhonen, T.K. Invited review, Breaking barriers, attack on innate immune defences by omptin surface proteases of enterobacterial pathogens. Innate Immun. 2009, 15, 67-80. [CrossRef] [PubMed]

75. Nair, M.K.; Venkitanarayanan, K.; Silbart, L.K.; Kim, K.S. Outer membrane protein A (OmpA) of Cronobacter sakazakii binds fibronectin and contributes to invasion of human brain microvascular endothelial cells. Foodborne Pathog. Dis. 2009, 6, 495-501. [CrossRef]

76. Eshwar, A.K.; Tall, B.D.; Gangiredla, J.; Gopinath, G.R.; Patel, I.R.; Neuhauss, S.C.; Stephan, R.; Lehner, A. Linking genomo- and pathotype, Exploiting the zebrafish embryo model to investigate the divergent virulence potential among Cronobacter spp. PLoS ONE 2016, 11, e0158428. [CrossRef] [PubMed]

77. Kumar, S.; Stecher, G.; Tamura, K. MEGA7, Molecular evolutionary genetics analysis version 7.0 for Bigger Datasets. Mol. Biol. Evol. 2016, 33, 1870-1874. [CrossRef] [PubMed]

78. Ghigo, J.M.; Wandersman, C. A carboxyl-terminal four-amino acid motif is required for secretion of the metalloprotease PrtG through the Erwinia chrysanthemi protease secretion pathway. J. Biol. Chem. 1994, 269, 8979-8985. [PubMed]

79. Miyoshi, S.; Kawata, K.; Tomochika, K.; Shinoda, S.; Yamamoto, S. The C-terminal domain promotes the hemorrhagic damage caused by Vibrio vulnificus metalloprotease. Toxicon 2001, 39, 1883-1886. [CrossRef]

80. Miyoshi, S.; Kawata, K.; Hosokawa, M.; Tomochika, K.; Shinoda, S. Histamine-releasing reaction induced by the N-terminal domain of Vibrio vulnificus metalloprotease. Life Sci. 2003, 72, 2235-2242. [CrossRef]

81. Miyoshi, S.; Shinoda, S. Microbial metalloproteases and pathogenesis. Microbes Infect. 2000, 2, 91-98. [CrossRef]

82. Finkelstein, R.A.; Boesman-Finkelstein, M.; Holt, P. Vibrio cholerae hemagglutinin/lectin/protease hydrolyzes fibronectin and ovomucin, F.M. Burnet revisited. Proc. Natl. Acad. Sci. USA 1983, 80, 1092-1095. [CrossRef]

83. Kothary, M.H.; Mccardell, B.A.; Frazar, C.D.; Deer, D.; Tall, B.D. Characterization of the zinc-containing metalloprotease encoded by zpx and development of a species-specific detection method for Enterobacter sakazakii. Appl. Environ. Microbiol. 2007, 73, 4142-4151. [CrossRef]

84. Eshwar, A.K.; Wolfrum, N.; Stephan, R.; Fanning, S.; Lehner, A. Interaction of matrix metalloproteinase-9 and Zpx in Cronobacter turicensis LMG 23827(T) mediated infections in the zebrafish model. Cell. Microbiol. 2018, 20, e12888. [CrossRef] [PubMed]

85. Pagotto, F.J.; Nazarowec-White, M.; Bidawid, S.; Bidawid, S.; Farber, J.M. Enterobacter sakazakii, infectivity and enterotoxin production in vitro and in vivo. J. Food Prot. 2003, 66, 370-375. [CrossRef] [PubMed]

86. Cruz, A.; Xicohtencatl-Cortes, J.; Gonzalez-Pedrajo, B.; Bobadilla, M.; Eslava, C.; Rosas, I. Virulence traits in Cronobacter species isolated from different sources. Can. J. Microbiol. 2011, 57, 735-744. [CrossRef] [PubMed] 
87. Singh, N.; Goel, G.; Raghav, M. Insights into virulence factors determining the pathogenicity of Cronobacter sakazakii. Virulence 2015, 6, 433-440. [CrossRef]

88. Jang, H.; Chase, H.R.; Gangiredla, J.; Gopinath, G.R.; Grim, C.J.; Patel, I.R.; Kothary, M.H.; Jackson, S.A.; Mammel, M.K.; Carter, L.; et al. Analysis of the molecular diversity among Cronobacter species isolated from filth flies using a pan genomic DNA microarray and whole genome sequencing. Front. Microbiol. 2019. submitted.

89. Stoop, B.; Lehner, A.; Iversen, C.; Fanning, S.; Stephan, R. Development and evaluation of rpoB based PCR systems to differentiate the six proposed species within the genus Cronobacter. Int. J. Food Microbiol. 2009, 136, 165-168. [CrossRef]

90. Lehner, A.; Fricker-Feer, C.; Stephan, R. Identification of the recently described Cronobacter condimenti by an rpoB-gene-based PCR system. J. Med. Microbiol. 2012, 61, 1034-1035. [CrossRef]

91. Carter, L.; Lindsey, L.A.; Grim, C.J.; Sathyamoorthy, V.; Jarvis, K.G.; Gopinath, G.; Lee, C.; Sadowski, J.A.; Trach, L.; Pava-Ripoll, M.; et al. Multiplex PCR assay targeting a diguanylate cyclase-encoding gene, $\operatorname{cg}_{c} A$, to differentiate species within the genus Cronobacter. Appl. Environ. Microbiol. 2013, 79, 734-737. [CrossRef]

92. Umeda, N.S.; De Filippis, I.; Forsythe, S.J.; Brandão, M.L.L. Phenotypic characterization of Cronobacter spp. strains isolated from foods and clinical specimens in Brazil. Food Res. Int. 2017, 102, 61-67. [CrossRef]

93. Richardson, K. Roles of motility and flagellar structure in pathogenicity of Vibrio cholerae, analysis of motility mutants in three animal models. Infect. Immun. 1991, 59, 2727-2736. [CrossRef]

94. Raghav, M.; Aggarwal, P.K. Purification and characterization of Enterobacter sakazakii enterotoxin. Can. J. Microbiol. 2007, 53, 750-755. [CrossRef] [PubMed]

95. Horne, S.M.; Kottom, T.J.; Nolan, L.K.; Young, K.D. Decreased intracellular survival of an fkpA mutant of Salmonella Typhimurium Copenhagen. Infect. Immun. 1997, 65, 806-810. [CrossRef] [PubMed]

96. Humphreys, S.; Rowley, G.; Stevenson, A.; Kenyon, W.J.; Spector, M.P.; Roberts, M. Role of periplasmic peptidylprolyl isomerases in Salmonella enterica serovar Typhimurium virulence. Infect. Immun. 2003, 71, 5386-5388. [CrossRef] [PubMed]

97. Eshwar, A.K.; Tasara, T.; Stephan, R.; Lehner, A. Influence of FkpA variants on survival and replication of Cronobacter spp. in human macrophages. Res. Microbiol. 2015, 166, 186-195. [CrossRef] [PubMed]

98. Costa, T.R.; Felisberto-Rodrigues, C.; Meir, A.; Prevost, M.S.; Redzej, A.; Trokter, M.; Waksman, G. Secretion systems in Gram-negative bacteria, structural and mechanistic insights. Nat. Rev. Microbiol. 2015, 13, 343-359. [CrossRef]

99. Cascales, E.; Christie, P.J. The versatile bacterial type IV secretion systems. Nat. Rev. Microbiol. 2003, 1, 137-149. [CrossRef]

100. Nunn, D. Bacterial type II protein export and pilus biogenesis, more than just homologies? Trends Cell Biol. 1999, 9, 402-408. [CrossRef]

101. Johnson, C.M.; Grossman, A.D. Integrative and Conjugative Elements (ICEs), What They Do and How They Work. Annu. Rev. Genet. 2015, 49, 577-601. [CrossRef]

102. Grim, C.J.; Kotewicz, M.L.; Power, K.A.; Gopinath, G.; Franco, A.A.; Jarvis, K.G.; Yan, Q.Q.; Jackson, S.A.; Sathyamoorthy, V.; Hu, L.; et al. Pan-genome analysis of the emerging foodborne pathogen Cronobacter spp. suggests a species-level bidirectional divergence driven by niche adaptation. BMC Genom. 2013, 14, 366. [CrossRef]

103. Schmid, M.; Iversen, C.; Gontia, I.; Stephan, R.; Hofmann, A.; Hartmann, A.; Jha, B.; Eberl, L.; Riedel, K.; Lehner, A. Evidence for a plant-associated natural habitat for Cronobacter spp. Res. Microbiol. 2009, 160, 608-614. [CrossRef]

104. Chase, H.R.; Eberl, L.; Stephan, R.; Jeong, H.; Lee, C.; Finkelstein, S.; Negrete, F.; Gangiredla, J.; Patel, I.; Tall, B.D.; et al. Draft genome sequence of Cronobacter sakazakii GP1999, sequence type 145, an epiphytic isolate obtained from the tomato's rhizoplane/rhizosphere continuum. Genome Announc. 2017, 5, e00723-17. [CrossRef] [PubMed]

105. Lee, V.T.; Schneewind, O. Protein secretion and the pathogenesis of bacterial infections. Genes Dev. 2001, 15, 1725-1752. [CrossRef] [PubMed]

106. Henderson, I.R.; Navarro-Garcia, F.; Nataro, J.P. The great escape, structure and function of the autotransporter proteins. Trends Microbiol. 1998, 6, 370-378. [CrossRef]

107. Veiga, E.; Sugawara, E.; Nikaido, H.; de Lorenzo, V.; Fernández, L.A. Export of autotransported proteins proceeds through an oligomeric ring shaped by C-terminal domains. EMBO J. 2002, 21, 2122-2131. [CrossRef] 
108. Kothary, M.H.; Gopinath, G.R.; Gangiredla, J.; Rallabhandi, P.V.; Harrison, L.M.; Yan, Q.Q.; Chase, H.R.; Lee, B.; Park, E.; Yoo, Y.; et al. Analysis and characterization of proteins associated with outer membrane vesicles secreted by Cronobacter spp. Front. Microbiol. 2017, 8, 134. [CrossRef] [PubMed]

109. Bernardini, M.L.; Mounier, J.; D’hauteville, H.; Coquis-Rondon, M.; Sansonetti, P.J. Identification of $i c s A$, a plasmid locus of Shigella flexneri that governs bacterial intra- and intercellular spread through interaction with F-actin. Proc. Natl. Acad. Sci. USA 1989, 86, 3867-3871. [CrossRef] [PubMed]

110. Bonemann, G.; Pietrosiuk, A.; Diemand, A.; Zentgraf, H.; Mogk, A. Remodelling of VipA/VipB tubules by $\mathrm{ClpV-mediated} \mathrm{threading} \mathrm{is} \mathrm{crucial} \mathrm{for} \mathrm{type} \mathrm{VI} \mathrm{protein} \mathrm{secretion.} \mathrm{EMBO} \mathrm{J.} \mathrm{2009,} \mathrm{28,} \mathrm{315-325.} \mathrm{[CrossRef]}$

111. Jani, A.J.; Cotter, P.A. Type VI secretion, not just for pathogenesis anymore. Cell Host Microbe 2010, 8, 2-6. [CrossRef]

112. Boyer, F.; Fichant, G.; Berthod, J.; Vandenbrouck, Y.; Attree, I. Dissecting the bacterial type VI secretion system by a genome wide in silico analysis, what can be learned from available microbial genomic resources? BMC Genomics. 2009, 10, 104. [CrossRef]

113. Wang, M.; Cao, H.; Wang, Q.; Xu, T.; Guo, X.; Liu, B. The roles of two type VI secretion systems in Cronobacter sakazakii ATCC 12868. Front. Microbiol. 2018, 9, 2499. [CrossRef]

114. Whitehead, N.A.; Barnard, A.M.; Slater, H.; Simpson, N.J.; Salmond, G.P. Quorum-sensing in Gram-negative bacteria. FEMS Microbiol. Rev. 2001, 25, 365-404. [CrossRef] [PubMed]

115. Waters, C.M.; Bassler, B.L. Quorum sensing, cell-to-cell communication in bacteria. Annu. Rev. Cell Dev. Biol. 2005, 21, 319-346. [CrossRef] [PubMed]

116. Reading, N.C.; Sperandio, V. Quorum sensing, the many languages of bacteria. FEMS Microbiol. Lett. 2006, 254, 1-11. [CrossRef] [PubMed]

117. Ryan, R.P.; Dow, J.M. Diffusible signals and interspecies communication in bacteria. Microbiology 2008, 154, 1845-1858. [CrossRef] [PubMed]

118. Hawver, L.A.; Jung, S.A.; Ng, W.L. Specificity and complexity in bacterial quorum-sensing systems. FEMS Microbiol. Rev. 2016, 40, 738-752. [CrossRef]

119. Pinton, U.M.; Vianna, E.S.; Martins, M.L.; Vanetti, M.C.D. Detection of acylated homoserine lactones in Gram negative proteolytic psychotrophic bacteria isolated from cooled raw milk. Food Control 2007, 18, 1322-1327. [CrossRef]

120. Da Silva Araújo, F.D.; Esper, L.M.; Kuaye, A.Y.; Sircili, M.P.; Marsaioli, A.J. N-acyl-homoserine lactones from Enterobacter sakazakii (Cronobacter spp.) and their degradation by Bacillus cereus enzymes. J. Agric. Food Chem. 2012, 60, 585-592. [CrossRef]

121. Bofinger, M.R.; de Sousa, L.S.; Fontes, J.E.N.; Marsaioli, A.J. Diketopiperazines as cross-communication quorum-sensing signals between Cronobacter sakazakii and Bacillus cereus. ACS Omega 2017, 2, 1003-1008. [CrossRef]

122. Holden, M.T.; Ram Chhabra, S.; de Nys, R.; Stead, P.; Bainton, N.J.; Hill, P.J.; Manefield, M.; Kumar, N.; Labatte, M.; England, D. Quorum-sensing cross talk, isolation and chemical characterization of cyclic dipeptides from Pseudomonas aeruginosa and other Gram-negative bacteria. Mol. Microbiol. 1999, 33, 1254-1266. [CrossRef]

123. Degrassi, G.; Aguilar, C.; Bosco, M.; Zahariev, S.; Pongor, S.; Venturi, V. Plant growth-promoting Pseudomonas putida WCS358 produces and secretes four cyclic dipeptides, cross-talk with quorum sensing bacterial sensors. Curr. Microbiol. 2002, 45, 250-254. [CrossRef]

124. Tall, B.D.; Chase, H.R.; Gopinath, G.R. Editorial: Diverse profiles of N-acyl-homoserine lactones in biofilm forming isolates of Cronobacter sakazakii. Virulence 2017, 8, 246-247. [CrossRef] [PubMed]

125. Elgaml, A.; Miyoshi, S.I. Regulation systems of protease and hemolysin production in Vibrio vulnificus. Microbiol. Immunol. 2017, 61, 1-11. [CrossRef] [PubMed]

126. Singh, N.; Patil, A.; Prabhune, A.A.; Raghav, M.; Goel, G. Diverse profiles of N-acyl-homoserine lactones in biofilm forming strains of Cronobacter sakazakii. Virulence 2017, 8, 275-281. [CrossRef] [PubMed]

127. Ye, Y.; Gao, J.; Jiao, R.; Li, H.; Wu, Q.; Zhang, J.; Zhong, X. The membrane proteins involved in virulence of Cronobacter sakazakii virulent G362 and attenuated L3101 isolates. Front. Microbiol. 2015, 6, 1238. [CrossRef]

128. Townsend, S.; Caubilla Barron, J.; Loc-Carrillo, C.; Forsythe, S. The presence of endotoxin in powdered infant formula milk and the influence of endotoxin and Enterobacter sakazakii on bacterial translocation in the infant rat. Food Microbiol. 2007, 24, 67-74. [CrossRef] 
129. Jang, H.; Addy, N.; Ewing, L.; Beaubrun, J.J.; Lee, Y.; Woo, J.; Negrete, F.; Finkelstein, S.; Tall, B.D.; Lehner, A.; et al. Whole-genome sequences of Cronobacter sakazakii isolates obtained from foods of plant origin and dried-food manufacturing environments. Genome Announc. 2018, 6, e00223-18. [CrossRef]

130. Jang, H.; Woo, J.; Lee, Y.; Negrete, F.; Finkelstein, S.; Chase, H.R.; Addy, N.; Ewing, L.; Beaubrun, J.J.; Patel, I.; et al. Draft genomes of Cronobacter sakazakii strains isolated from dried spices bring unique insights into the diversity of plant-associated strains. Stand. Genom. Sci. 2018, 13, 35. [CrossRef]

131. Afridi, M.S.; Mahmood, T.; Salam, A.; Mukhtar, T.; Mehmood, S.; Ali, J.; Khatoon, Z.; Bibi, M.; Javed, M.T.; Sultan, T.; et al. Induction of tolerance to salinity in wheat genotypes by plant growth promoting endophytes, Involvement of ACC deaminase and antioxidant enzymes. Plant Physiol. Biochem. 2019, 139, 569-577. [CrossRef]

132. Feeney, A.; Sleator, R.D. An in-silico analysis of osmotolerance in the emerging gastrointestinal pathogen Cronobacter sakazakii. Bioeng. Bugs 2011, 2, 260-270. [CrossRef]

133. Riedel, K.; Lehner, A. Identification of proteins involved in osmotic stress response in Enterobacter sakazakii by proteomics. Proteomics 2007, 7, 1217-1231. [CrossRef]

134. Srikumar, S.; Cao, Y.; Yan, Q.; Van Hoorde, K.; Nguyen, S.; Cooney, S.; Gopinath, G.R.; Tall, B.D.; Sivasankaran, S.K.; Lehner, A.; et al. RNA sequencing-based transcriptional overview of xerotolerance in Cronobacter sakazakii SP291. Appl. Environ. Microbiol. 2019, 85, e01993-18. [CrossRef] [PubMed]

135. Edelson-Mammel, S.G.; Buchanan, R.L. Thermal inactivation of Enterobacter sakazakii in rehydrated infant formula. J Food Prot. 2004, 67, 60-63. [CrossRef] [PubMed]

136. Williams, T.L.; Monday, S.R.; Edelson-Mammel, S.; Buchanan, R.; Musser, S.M. A top-down proteomics approach for differentiating thermal resistant strains of Enterobacter sakazakii. Proteomics 2005, 5, 4161-4169. [CrossRef] [PubMed]

137. Gajdosova, J.; Benedikovicova, K.; Kamodyova, N.; Tothova, L.; Kaclikova, E.; Stuchlik, S.; Turna, J.; Drahovska, H. Analysis of the DNA region mediating increased thermotolerance at 58 degrees $\mathrm{C}$ in Cronobacter sp. and other enterobacterial strains. Antonie Van Leeuwenhoek 2011, 100, 279-289. [CrossRef] [PubMed]

138. Yan, Q.; Power, K.A.; Cooney, S.; Fox, E.; Gopinath, G.R.; Grim, C.J.; Tall, B.D.; McCusker, M.P.; Fanning, S. Complete genome sequence and phenotype microarray analysis of Cronobacter sakazakii SP291, a persistent isolate cultured from a powdered infant formula production facility. Front. Microbiol. 2013, 4, 256. [CrossRef] [PubMed]

139. Mercer, R.G.; Walker, B.D.; Yang, X.; McMullen, L.M.; Ganzle, M.G. The locus of heat resistance (LHR) mediates heat resistance in Salmonella enterica, Escherichia coli and Enterobacter cloacae. Food Microbiol. 2017, 64, 96-103. [CrossRef] [PubMed]

140. Koronakis, V.; Sharff, A.; Koronakis, E.; Luisi, B.; Hughes, C. Crystal structure of the bacterial membrane protein TolC central to multidrug efflux and protein export. Nature 2000, 405, 914-919. [CrossRef]

141. Brown, D.G.; Swanson, J.K.; Allen, C. Two host-induced Ralstonia solanacearum genes, acrA and dinF, encode multidrug efflux pumps and contribute to bacterial wilt virulence. Appl. Environ. Microbiol. 2007, 73, 2777-2786. [CrossRef]

142. Bina, X.R.; Provenzano, D.; Nguyen, N.; Bina, J.E. Vibrio cholerae RND family efflux systems are required for antimicrobial resistance, optimal virulence factor production, and colonization of the infant mouse small intestine. Infect. Immun. 2008, 76, 3595-3605. [CrossRef]

143. Negrete, F.; Jang, H.; Gangiredla, J.; Chase, H.R.; Woo, J.; Lee, Y.; Patel, I.; Finkelstein, S.B.; Tall, B.D.; Gopinath, G.R. Genome-wide survey of efflux pump-coding genes associated with Cronobacter survival, osmotic adaptation, and persistence. Curr. Opin. Food Sci. 2019, 30, 32-42. [CrossRef]

144. Power, K.A.; Yan, Q.; Fox, E.M.; Cooney, S.; Fanning, S. Genome sequence of Cronobacter sakazakii SP291, a persistent thermotolerant isolate derived from a factory producing powdered infant formula. Genome Announc. 2013, 1, e00082-13. [CrossRef] [PubMed]

145. Zhao, Z.; Wang, L.; Wang, B.; Liang, H.; Ye, Q.; Zeng, M. Complete genome sequence of Cronobacter sakazakii strain CMCC 45402. Genome Announc. 2014, 2, e01139-13. [CrossRef]

146. Diaz-Orejas, R.; Espinosa, M.; Yeo, C.C. The importance of the expendable, Toxin-antitoxin genes in plasmids and chromosomes. Front. Microbiol. 2017, 8, 1479. [CrossRef] [PubMed] 
147. Tall, B.D.; Gopinath, G.; Gangiredla, J.; Patel, I.R.; Fanning, S.; Lehner, A. Chapter 14. Cronobacter species. In Food Microbiology, Fundamentals and Frontiers, 5th ed.; Doyle, M.P., Diez-Gonzalez, F., Hill, C., Eds.; ASM Press: Washington, DC, USA, 2019. Available online: https://www.asmscience.org/content/book/10.1128/ 9781555819972.ch14 (accessed on 17 January 2020).

148. Finlay, B.B.; Falkow, S. Common themes in microbial pathogenicity. Microbiol. Rev. 1989, 53, $210-230$. [CrossRef] [PubMed]

149. Thanassi, D.G.; Nuccio, S.P.; Shu Kin So, S.; Bäumler, A.J. Fimbriae: Classification and Biochemistry. EcoSal Plus. 2007, 2. [CrossRef] [PubMed]

150. Humphries, A.D.; Townsend, S.M.; Kingsley, R.A.; Nicholson, T.L.; Tsolis, R.M.; Bäumler, A.J. Role of fimbriae as antigens and intestinal colonization factors of Salmonella serovars. FEMS Microbiol. Lett. 2001, 201, 121-125. [CrossRef] [PubMed]

151. Hu, L. Prevalence of curli genes among Cronobacter species and their roles in biofilm formation and cell-cell aggregation. Int. J. Food Microbiol. 2018, 265, 65-73. [CrossRef]

152. Wattam, A.R.; Abraham, D.; Dalay, O.; Disz, T.L.; Driscoll, T.; Gabbard, J.L.; Gillespie, J.J.; Gough, R.; Hix, D.; Kenyon, R.; et al. PATRIC, the bacterial bioinformatics database and analysis resource. Nucleic Acids Res. 2014, 42, D581-D591. [CrossRef]

153. Schaible, U.E.; Kaufmann, S.H. Iron and microbial infection. Nat. Rev. Microbiol. 2004, 2, 946-953. [CrossRef]

154. Gurtler, J.B.; Kornacki, J.L.; Beuchat, L.R. Enterobacter sakazakii, a coliform of increased concern to infant health. Int. J. Food Microbiol. 2005, 104, 1-34. [CrossRef]

155. Farmer, J.J., 3rd. My 40-Year History with Cronobacter/Enterobacter sakazakii-Lessons learned, myths debunked, and recommendations. Front. Pediatr. 2015, 3, 84. [CrossRef] [PubMed]

(C) 2020 by the authors. Licensee MDPI, Basel, Switzerland. This article is an open access article distributed under the terms and conditions of the Creative Commons Attribution (CC BY) license (http://creativecommons.org/licenses/by/4.0/). 